\title{
Öğretmen Adaylarının Türk Eğitim Sisteminin Sorunlarına Olan Yaklaşımı ve Kültürel Bazda Küresel Problemlere Yakınlık Düzeyleri
}

\author{
DOI: 10.26466/opus.773110
}

*

\section{Eray Eğmir ${ }^{*}$ - Halit Çelik **}

*Dr. Öğr Üyesi, Afyon Kocatepe Üniversitesi, Eğitim Fakültesi, Afyonkarahisar/Türkiye E-Posta: eegmir@aku.edu.tr ORCID: 0000-0003-3054-1011

**Dr. Öğr. Üyesi., Kütahya Dumlupınar Üniversitesi, Altıntaş M.Y.O., Kütahya/Türkiye E-Posta: hacel2015@gmai.com ORCID: $\quad$ 0000-0001-7083-6127

\section{$\ddot{O} z$}

Bu çalışma öğretmen adaylarının eğitim sisteminin sorunlarına ilişkin görüşlerinin dünyadaki yeni problemler/kültür alanlar ile örtüşüp örtüşmediğini belirlemeyi amaçlamaktadır. Araştırma nitel desende tasarlanmış bir araştırma olup öğretmen adaylarının görüşlerinin fenomenolojik bir yaklaşımla derinlemesine analiz edilmiştir. Veriler araştırmacılar tarafından hazırlanmış bir yarı yapılandırılmış görüşme formu kullanılarak toplanmış ve içerik analizi ile analiz edilmiştir. Katılımcılar bir devlet üniversitesinde öğrenim gören 60 öğretmen adayından oluşmaktadır. Öğretmen adaylarının görüşleri, eğitimin işlevlerini yerine getirememesi, ezberci yapı, firsat eşitliği, lisans eğitiminin niteliği, değer eğitimi, sistemin istikrarsı oluşu, öğretmene ilişkin politikalar, kaynak eksikliği, ithal eğitim sistemlerinin uygulamalarının transfer edilmesi, yetişkin eğitimi, eğitimin paydaşlarına yönelik problemler gibi başlıklarda yoğunluk göstermektedir. Buna göre öğretmen adaylarının kamuoyunda tartışlan eğitim problemlerine duyarlı oldukları ama dünya genelinde gerçekleşen veya gerçekleşmesi muhtemel eğitim problemlerine ilişkin farkındalıklarının düşük olması nedeniyle hazırlıssı oldukları görülmektedir. Bu doğrultuda öğretmen adaylarına formasyon dersleri ve akademik araştırma sahalarında küresel eğitim sorunları ve öngörülen problemler doğrultusunda eğitimler verilmesi önem arz etmektedir.

Anahtar Kelimeler: eğitim sistemi, milli eğitim sistemi, eğitimin sorunları, öğretmen adayları. 


\title{
Pre-Service Teachers' Approaches to the Problems of the Turkish Education System and Levels of Closeness to Global Problems on a Cultural Basis
}

\begin{abstract}
This study aims to determine whether teacher candidates' views on the problems of the education system overlap with new problems/cultural areas in the world. The research is a research designed in a qualitative pattern and the opinions of teacher candidates were analyzed in depth with a phenomenological approach. The data were collected using a semi-structured interview form prepared by the researchers and analyzed by content analysis. Participants consist of 60 teacher candidates studying at a public university. Pre-service teachers' views showed that, the inability of education to fulfill its functions, having a structure that gives importance to memorization, equality in opportunity, quality of undergraduate education, value education, instability of the system, policies regarding the teacher, lack of resources, transfer of implementations of imported education systems, adult education, problems for education stakeholders areas are the problem areas of Turkish education system. Accordingly, it is seen that pre-service teachers are sensitive to the education problems discussed in the public, but because of their low awareness of the education problems that occur or are likely to occur worldwide they are unprepared towards this kind of problems. In this regard, it is important to provide training courses and academic research activities to pre-service teachers in line with global education problems and foreseen problems.
\end{abstract}

Keywords: education system, national education system, problems of the education, pre-service teachers. 


\section{Giriş}

Eğitim sosyal yapıyı oluşturan en önemli kurumlardan biri olarak görülmektedir. Tüm sosyal kurumlarla sıkı bir etkileşim içerisinde olması nedeniyle eğitim sistem ve kurumlarına tüm bu kurumlardan yoğu biçimde dönüt gelmektedir. Eğitim yapabildikleri ve de özellikle de yapamadıklarıyla ülkenin gündemini sıklıkla meşgul etmektedir. Eğitimin bir ülkenin küresel ölçekteki konumunu belirleyen kritik bir alan olması siyasi, toplumsal ve ekonomik tüm zeminlerde eğitimin önemli bir başlık olarak alınmasını zorunlu kılmaktadır. Eğitim olgusunun performansını etkileyen bileşenler karmaşık bir ilişkiler ağı oluşturmaktadır. Eğitimin içerisinden ve dışından birçok etmen bu performansa etki ederken, olumsuz durumlar da sürekli toplum tarafindan mercek altına alınmaktadır.

19. yüzyılda geleneksel yapısında ve anlayışında köklü değişiklikler meydana gelen eğitim olgusu tüm ülkelerde olduğu gibi ülkemizde de yeni paradigma arayışlarının oluşmasına sebep olmuştur. Eğitimin tüm bileşenlerini etkileyen felsefi yönelimdeki bu arayış zamanla eğitimin yönünün, yöntemlerinin ve sonuçlarının da tartsşılmaya başladığı bütüncül bir müzakere zeminine dönüşmüştür. Günümüzde eğitimin temelde paradigmasına dönük yapılandırma çabaları ve bu çabalara getirilen eleştiriler eğitim sorunlarına dair tartışmanın önemli bir kısmını oluşturmaktadır.

Avrupa'nın öğrenci potansiyeli bakımından başat ülkelerinden olan Türkiye, eğitim sisteminin sağlıklı yürüyebilmesi adına her yıl genel bütçenin önemli bir bölümünü eğitim öğretim faaliyetlerinin yürütülmesi ve geliştirilmesine ayırmaktadır. 2019 verilerine göre genel ülke bütçesinin \%15,28'inin (146 836368000 TL) eğitim sistemi için ayrılması Türkiye Cumhuriyeti devletinin eğitime verdiği önemi göstermektedir (MEB, 2019a). Ama Türk eğitim sisteminin her dönemde farklı sorunlar barındırması nedeniyle bu sorunlar ile mücadele edilmesi ve bu sorunlar çerçevesinde geçici ya da kalıcı çözümler üretilmesi başta Milli Eğitim camiası olmak üzere eğitimin tüm paydaşlarını ilgilendiren hususlar olmuştur. Yılmaz ve Altınkurt (2011, s.944-945) yaptıkları çalışmada çeşitli kurum ve kuruluşların dile getirdiği eğitime dair birçok sorunu tablo halinde derlemiş ve bu sorunların çözümü için yapılan çalışmaların yetersiz kaldığını belirtmiştir.

Eğitim alanındaki sorunlar ülke geneli için yapılan çalışmaların yanında yerel düzeyde oluşturulan çalışmaların konusu olarak da ele alınmaktadır. 
Ünal, Yavuz ve Küçükler (2011)'in Konya ili için yapmış oldukları çalışmada ilköğretim müfettişlerince düzenlenen öğretim yılı sonu raporları baz alınarak eğitime dair bazı sorunlar tespit edilmiştir. Buna göre en fazla belirtilen sorunlar, öğretmen atama ve görevlendirmesi ile denetim yapısına ilişkindir. Sonuçlar ışı̆̆ında Konya ilinin eğitim sorunlarının Türkiye'nin genel eğitim sorunları ile benzerlik gösterdiği söylenebilir (Ünal, Yavuz ve Küçüker, 2011, s.272). Yerel bazda görülen sorunlar ile ülke genelindeki sorunların örtüşmesi eğitim problemlerinin sistematik bir şekilde var olduğunu göstermektedir. Ama bu problemlerin Türk eğitim sisteminin ana problemleri olup olmadığı ve bu sorunların küresel bazda eğitim alanındaki gelişim ve değişim içerisindeki yeri tartışılması gereken durumlardır.

Çalışma grubunu tek bir şehirdeki bireylerin oluşturduğu akademik çalışmaların birçoğunda çeşitli eğitim problemleri dile getirilmiştir. Bu çalışmaların bazen öğretmen odaklı bazen de eğitim ortamı merkeze alınarak gerçekleştirildiği görülmektedir. Bunun yanı sıra bu çalışmalarda öne sürülen problem alanları birbiriyle büyük oranda benzerlik göstermektedir. Demir ve Arı (2013) tarafından yapılan çalışmada, öğretmenlerin en fazla önemsedikleri sorunlar, gelirin düşük olması, toplum içindeki saygınlıklarının azalması ve sıklıkla değişen eğitim ve öğretim programları-mevzuatları olarak belirlenmiştir. Seferoğlu (2001) tarafından gerçekleştirilen "Sınıf öğretmenlerinin kendi mesleki gelişimleriyle ilgili görüşleri, beklentileri ve önerileri" isimli çalışmada da paralel sonuçlarla karşılaşılmaktadır Aynı çalışmanın sonuç bölümünde öğretmenlerin ekonomik problemlerinin çözülemediği vurgusu da yapılmaktadır.

Filiz ve Durnali (2009, s.403)'ye göre, programlar, öğretmenlerin öğretim sırasında karşılaşılabilecek zorlukları çözebilmeleri için materyal hazırlama, ders planlama ve ders içeriği gibi konulardan haberdar olmalarını sağlar. Ama programların da eğitim sisteminin güncel problemlerinin tümüne çözüm sağlayamayacağı gerçeği de göz ardı edilmemelidir. Bu noktada Posner (1995) göz ardı edilen program kavramını ortaya atmış ve okulun ve öğretmenlerin bilinçli veya bilinçsiz olarak bazı eğitsel öğeleri görmezden geldiğini ifade etmiştir. Bu göz ardı etme olgusu, bazı durumlarda hem okul içi hem de yaşamsal öğrenmelerde telafi edilemeyecek sonuçların doğmasina yol açmaktadır. Özetle, okullar ve öğretmenler sadece öğrettikleri şeylerden değil aynı zamanda göz ardı ettikleri eğitsel öğelerden de sorumlu ol- 
dukları (Eisner, 1985; akt. Orhan ve Acar, 2018) göz önüne alındığında, göz ardı edilen kısımların neden öğretilmediğinin tespiti önemli bir husustur.

Eğitim salt bir alan olarak kendi bağlamındaki sorunların yanı sıra diğer toplumsal, siyasal ve ekonomik sorunlardan da direkt olarak etkilenmektedir. Bu bakımdan eğitim sisteminin paydaşları diğer alanlarda görülen sorunların olumsuz etkilerini azaltıcı önlemleri de almak durumunda kalmaktadır. TSKB (Türkiye Sınai Kalkınma Bankası) Ekonomik Araştırmalar Birimi'nin 2014 yılında hazırlamış olduğu raporda eğitimin diğer sektörler ile teması ve bunun doğurduğu problemlerden bahsedilmektedir. Örneğin ilgili raporda tüm kamu çevreleri ve iş dünyası tarafından önemine sıkça değinilen mesleki ve teknik eğitime olan talebin artmasıyla, bu kademedeki derslik ihtiyacının artacağı öngörülmektedir. Sanayi ve eğitim işbirliğinin yadsınamaz bir gerçek olduğu da bu raporda analiz edilmiştir (ESK, 2014, s. 70). Eğitim alanındaki problemlerin yanında eğitim politikalarını oluşturan ve yürüten kurumlar arasındaki uyumsuzluk da eğitim açısından problem olarak algılanmaktadır. Yıldırım (2013, s. 188) gerek öğretmen eğitimcileri gerekse Millî Eğitim Bakanlığı tarafından üzerinde uzlaşılan öğretmen yeterliklerinin olmadığını ifade etmiştir. Başka bir deyişle YÖK ve MEB tarafından ortaya konmuş öğretmen yeterlikleri var ise de bunlar üzerinde henüz bir görüş birliği oluşmamıştır.

Eğitimin kalbini oluşturan öğretmen olgusu eğitimin sorunlarının temelinde var olan bir olgu olarak karşımıza çıkmaktadır. Öğretmen kaynaklı problemler adına çeşitli derneklerin son yıllarda yaptıkları ve yayımladıklar1 eğitim raporlarına göre eğitimde öğretmen performansının ve bu performansla doğrudan ilişkili olan eğitimin kalitesinin geliştirilmesi için etkili bir performans değerlendirme sisteminin tasarlanması ve uygulanması gerektiği belirtilmektedir (EDR, 2019, s. 81). Ayrıca öğretmenlerin özlük ve kişisel haklarının önemli olduğu vurgulanarak bu yönde önerilerin de sunulduğu görülmektedir. Eğitim Reformu Girişimi tarafından 2019 yılında yayımlanan "Öğretmenler" başlıklı raporda öğretmenlere ilişkin her türlü düzenlemenin, mesleğin statüsüne ve itibarına nasıl etki ettiği göz önünde bulundurularak tartışılması gerektiği ifade edilmiştir. Öğretmenlerin kendilerini ilgilendiren düzenlemelerde söz sahibi olmaları için katılım mekanizmalarının oluşturulması gerektiği raporda belirtilen hususlardandır (ERG, 2019, s. 39). Bu sonuçlara bakıldığında öğretmenlerin yaptıkları işteki motivasyon durumları önem kazanmaktadır. Akbaşlı, Okan ve Durnalı (2020, s. 573)'nın 
çalışmasına göre, öğretmen motivasyonuna ilişkin dağılımlara bakıldığında içsel motivasyon boyutunda ortalamanın yüksek, dişsal motivasyon boyutunda ise düşük olduğu tespit edilmiştir. Öğretmenler yaptıkları işin değerli olduğunu düşünmektedirler. Öğretmenlerin yaptıkları işte kendilerini başarılı gördükleri ve işlerini isteyerek yaptıkları söylenebilir. Böyle bir durumda öğretmenler kendilerini görev yaptıkları okulun önemli bir parçası olarak görebilir. Eğitimin her alanında öğrenici ve öğreticilerden beklenen temel olguların olduğu unutulmamalıdır. Limon \& Durnalı (2018, s.28)'ya göre "doktora programlarında özellikle alanın felsefesine ve mantık ilkelerine odaklanılmalı, iyi bir bilim insanı öncelikle kendi anadiline hâkim olmalı, süreç içerisinde öğrenci sadece danışmanı ile değil diğer paydaşlarla da iş birliği içerisine girmelidir. Bu doğrultuda Türkiye Cumhuriyet'inin eğitim politikalarını belirleyen başta MEB olmak üzere tüm kurum ve kuruluşlar mevcut sorunlar üzerine mottolar üretmektedir. MEB'in sorunlar üzerine ürettiği mottosu "Bugünün sorunlarına çözüm üretirken yarını tehlikeye atmadan, dünün çözümlerini mükemmelleştirmeden, yeni bir anlayış yaratarak bizden olan ama aynı zamanda bizden farklı çocuklar yetişmesi için ortak bir hedefe ilerleyeceğiz" (MEB, 2019b, s. 128) olarak belirlenmiştir.

Özyılmaz (2020)’ın kaleme aldığ1 “Türk Milli Eğitim Sisteminin Sorunları ve Çözüm Arayışları" adlı kitapta çeşitli sorunlar başlıklar halinde ele alınmış ve çözüm önerileri sunulmuştur. Akademinin özellikle milli eğitim ile ilgili çalışmaları ve sorunlara olan tepkisi önemlidir. Kitapta yer alan bazı eğitim sorunları şu şekildedir (Özyılmaz, 2020):

a) Eğitime yönelik çalışmalarda ideolojik yaklaşımların egemen olması.

b) Eğitim sisteminin geliştirilmesinde, eğitim bilimcilerden yeteri derecede yararlanılmaması.

c) Eğitimin millileştirilememiş olması.

d) Eğitimde program geliştirme çalışmalarının olmaması.

e) Türkiye'de öğretmen sorunu ya da öğretmenin yetiştirilmesi ve istihdamı meselesi.

Millî Eğitim Bakanlığının eğitim alanındaki sorunları çözme çabası sorunların yaygın ve dağınık bir yapı oluşturması sebebi ile zor ve meşakkatli bir durum arz etmektedir. Mesela, Millî Eğitim Bakanlığının 2019-2023 stratejik planında "Yurt dışında çalışan veya ikamet eden Türk vatandaşlarının eğitim ve öğretim alanındaki ihtiyaç ve sorunlarına yönelik çalışmaları ilgili 
kurum ve kuruluşlarla iş birliği içinde yürütmek" şeklinde bir hususu dile getirmesi eğitim sorunlarının sadece yurt içinde değil yurt dışında da var olduğunu gözler önüne sermektedir (MEB, 2019b). Milli eğitim bakanlığının bu stratejik hedefleri zaman zaman siyasi ortamlarda tartısılmakta ve hakkında raporlar hazırlanmaktadır. Bu raporlar bazen dernekler bazen de sendikalar tarafından yayımlanmaktadır. Eğitim-Sen (2019)'in yayımladığ “2018-2019 Eğitim-Öğretim Yılında Eğitimin Durumu” adlı raporda, yeni ortaöğretim sistemi ile birlikte 9,10 ve 11 'inci sinfflardaki ders saatinin 40 'tan 35'e düşürülmesinin, ortaöğretimde görev yapan 70 bine yakın öğretmenin önümüzdeki dört yıl içinde norm fazlası haline gelmesine neden olacağı belirtilmiştir.

Yukarıda kısaca özetlenen eğitim ve eğitim problemlerine ilişkin rapor, değerlendireme, akademik çalışma ve toplanan verilere bakıldığında genel geçer problemlerin yüzeysel ve güncellenmemiş problemler olduğu tespiti yapılmıştır. Gelişen ve değişen dünya eğitim yapısı içerisinde çok farklı eğitim problemleri, geleceğin eğitim anlayışı, küresel eğitim fikirleri, doğabilecek eğitim kaynaklı problemler gibi yeni ve değişen problem başlıklarının değerlendirilmediği, dünya literatürünün takibinde sıkıntılar olduğu ve bu yönde yeni anlayış ve fikirlerin oluşmadığı söylenebilir. Bu bağlamda bu çalışmada kısır sorunlar etrafında dönen ve günü kurtaran öneri ve tekliflerin yerine küresel dünyanın sorunlarına ve gelecekte eğitim camiasını bekleyen sorunlara hazırlıklı olmak açısından neler yapılabileceği üzerine tespitlerde bulunmak amaçlanmıştır. Son dönemde dünyanın gündemini alt üst eden Covid 19 pandemisi eğitim dünyasına da yeni problemler doğurmuş ve mevcut tüm sorunların bir kenara atılmasına sebep olmuştur. Kültürel yeni yaklaşımlar, teknoloji kültürü, uzaktan eğitim kültürü, kültürlerarasılık, yapay zekâ kültürü vb. yeni alanlar eğitim camiasını da bekleyen sorunlar olarak düşünülmektedir. Doğan bu yeni problemlere ne kadar hazırlıklı olunduğu eğitim camiası tarafından tartışılmaktadır. Bu çalışma öğretmen adaylarının Türk Eğitim Sistemi'nin sorunlarına ilişkin görüşlerinin dünyadaki küresel ve yeni problemler/kültür alanları ile örtüşüp örtüşmediğini belirlemeyi amaçlamaktadır. 


\section{Yöntem}

Araştırma nitel desende tasarlanmış bir araştırma olup araştırmada öğretmen adaylarının Türk eğitim sisteminin sorunlarına ilişkin görüşlerinin fenomenolojik bir yaklaşımla derinlemesine analiz edilmesi hedeflenmiştir. Fenomenoloji deseni farkında olunan ancak derinlemesine ve ayrıntılı bir anlayışa sahip olunmayan olgulara odaklanır (Yıldırım ve Şimşek, 2011). Bu çalışmada da 12 yıllık bir zorunlu eğitimin ardından lisans eğitimine devam eden ve yaklaşık 15 yıldır bu sistemin içerisinde bulunan öğretmen adaylarının görüşleri sorunların belirlenmesi açısıyla toplanmıştır. Hem sistemin yapısından bu denli uzun bir süreç boyunca direkt etkilenmelerinin hem de eğitim fakültesi öğrencisi olmaları nedeniyle bu sistemin işleyişini ve bileşenlerini öğrendikleri bir lisans eğitimi almalarının sistemin sorunlarına dair görüşlerini olgunlaştırdığı düşünülmektedir. Araştırmanın çalışma grubunu maksimum çeşitleme yöntemi ile belirlenmiş 2019-2020 eğitim-öğretim yılında Ege Bölgesi'ndeki bir devlet üniversitesinin eğitim fakültesinde öğrenim gören öğrenciler oluşturmaktadır. Öğretmen adayları çalışma grubunun seçildiği eğitim fakültesinin beş farklı bölümünden ve dört farklı sınıf düzeyinden seçilmiş ve bu şekilde geniş bir katılımla veri toplanması amaçlanmıştır.

\section{Verilerin Toplanması ve Analizi}

Çalışmada ihtiyaç duyulan veriler araştırmacılar tarafından bir eğitim bilimleri ve bir dil uzmanının görüşleri de dikkate alınarak hazırlanmış bir yarı yapılandırılmış görüşme formu kullanılarak toplanmıştır. Veri toplama sürecinden önce ilgili üniversite etik kurulundan gerekli izinler alınmıştır. $\mathrm{Bu}$ çalışmanın etik açıdan bir sakınca taşımadığı Afyon Kocatepe Üniversitesi Sosyal ve Beşeri Bilimler Bilimsel Araştırma ve Yayın Etiği Kurulu'nun almış olduğu 27.05.2020 tarih ve E.17011 sayılı karar ile tespit edilmiştir.

Araştırmacıların hazırlamış olduğu görüşme formunda katılımcilardan Türk eğitim sisteminde önemli gördükleri sorunları nedenleriyle ifade etmeleri istenmiştir. Araştırmada ihtiyaç duyulan veriler, çalışma grubunu oluşturan öğrencilerden yazılı olarak toplanmıştır. Böylece daha çok sayıda katılımcıya ulaşılması ve katılımcıların görüşlerini yazılı olarak ifade etmesi yoluyla derinlemesine bilgi elde edilmesi hedeflenmiştir. 
Verilerin analizi nitel veri analiz yöntemlerinden içerik analizi kullanılarak gerçekleştirilmiştir. İçerik analizi, insan davranışlarını ve doğasını belirleme üzerine direkt olmayan metotlarla çalışma imkânı sunan bir tekniktir. Bu teknik, belirli kurallara dayalı kodlamalarla bir metnin bazı sözcüklerinin daha küçük içerik kategorileri ile özetlendiği hatta sayısallaştırıldığ sistematik bir tekniktir (Büyüköztürk, Kılıç Çakmak, Akgün, Karadeniz ve Demirel, 2013).

\section{Geçerlik, Güvenirlik, Etik}

Çalışmanın inanılırlığının ve tutarlığının sağlanması amacıyla sunulan veriler doğrudan alıntılarla desteklenmiştir. Bununla birlikte verilerin kodlanması aşamasında veriler iki araştırmacı tarafından ayrı ayrı kodlanmış ve kodlayıcılar arası tutarlılığın kontrol edilmesi amacıyla Miles ve Huberman modelinde içsel tutarlılık olarak adlandırılan kodlayıcılar arası görüş birliği hesaplanmıştır. Bu amaçla $\Delta=\mathrm{C} \div(\mathrm{C}+\partial) \times 100$ formülü kullanılarak hesaplama yapılmıştır. Formülde, $\Delta$ : Güvenirlik katsayısını, $C$ : Üzerinde görüş birliği sağlanan konu/terim sayısını ve d: Üzerinde görüş birliği bulunmayan konu/terim sayısını ifade etmektedir (Baltacı, 2017, s. 8). Hesaplama sonucunda kodlayıcılar arası görüş birliği oranının \%90 olduğu tespit edilmiştir. Bu oranın en az \%80 olması beklenmektedir, dolayısıyla araştırmacıların kodlamalarının içsel tutarlılığının yeterli düzeyde olduğu söylenebilir. Katılımclara kişisel bilgilerinin üçüncü şahıslarla paylaşılmayacağı beyan edildiğinden veriler raporlanırken isimler yerine katılımcı numaraları kullanılmıştır.

\section{Katılimcilar}

Katılımclar Ege Bölgesi'ndeki bir devlet üniversitesinde öğrenim gören 31 erkek ve 29 kadın olmak üzere toplam 60 öğretmen adayından oluşmaktadır. Öğrencilerin 18 tanesi okul öncesi öğretmenliği, 17 tanesi fen bilgisi öğretmenliği 15 tanesi ilköğretim matematik öğretmenliği, 6 tanesi bilgisayar ve öğretim teknolojileri öğretmenliği ve 4 tanesi ise sosyal bilgiler öğretmenliği öğrencilerinden oluşmaktadır. Fakültede aktif olan bölümlerin büyük kısmından öğrencinin çalışma grubuna dâhil edildiği görülmektedir. 


\section{Bulgular}

Bu bölümde öğretmen adaylarının Türk Eğitim Sisteminin sorunlarına ilişkin görüşlerine yer verilmiştir. Öncelikle sorunlara ilişkin genel bir tablo verilmiştir. Tablo 1'de öğretmen adaylarının, Türk Eğitim Sisteminin sorunlarına ilişkin görüşleri yer almaktadır.

Tablo 1. Türk Eğitim Sisteminin Sorunlarnna İlişkin Görüşler

\begin{tabular}{ll}
\hline Sorun & $\mathbf{f}$ \\
\hline Eğitimin ezberci yapısı & 58 \\
\hline Eğitimin bireyin gelişimini esas almaması & 48 \\
\hline Ö̆̆retmene ilişkin süreçler ve politikalar & 42 \\
\hline Eğitimin bireyi gerçek yaşama hazırlamadaki eksikliği & 35 \\
\hline Eğitim sisteminin istikrarsız oluşu & 27 \\
\hline Fiziki altyapı, donanım ve kaynak eksikliği & 20 \\
\hline Eğitimde fırsat ve imkân eşitsizliği & 15 \\
\hline Eğitimin öz farkındalık kazandırmada zafiyet göstermesi & 12 \\
\hline Eğitimin değer aktarmada zafiyet göstermesi & 10 \\
\hline Milli eğitime dair alınan kararları eğitim dışından kişilerin alması & 8 \\
\hline Eğitimin paydaşlarına yönelik problemler & 7 \\
\hline Lisans eğitiminin nitelik ve işlevinin düşük oluşu & 6 \\
\hline İthal eğitim sistemlerinin uygulamalarının transfer edilmesi & 6 \\
\hline Yetişkin eğitimine yeteri kadar önem verilmemesi & 6 \\
\hline Eğitim teknolojisinin yanlış yönde veya yetersiz kullanımı & 5 \\
\hline Okul öncesi eğitime erişim & 5 \\
\hline Okullaşma oranının az oluşu & 5 \\
\hline Eğitimin bilimsel temellere oturtulmaması & 2 \\
\hline Eğitim sisteminin merkeziyetçi yapısı & 1 \\
\hline Mesleki eğitimin önemsenmemesi & 1 \\
\hline Toplumsal cinsiyet eşitsizliği & 5 \\
\hline
\end{tabular}

\section{Ezberci Ĕ̆itim Sistemi}

Öğretmen adaylarının eğitim sistemine ilişkin ifade ettikleri en önemli sorunlardan biri ezberci eğitim sistemi teması altında toplanabilir. Toplam olarak 58 kez öğretmen adayları bu hususu bir problem alanı olarak ifade etmişlerdir. Bu tema altında öğretmen adaylarının çoğunluğu eğitimin sadece bilgi aktarma amacına odaklandığını ve bilgi aktarmaya odaklanmış sistemin öğrenciyi pasif bir duruma soktuğunu belirtmişlerdir. Bunun yanı sıra bilgi aktarma işlem ve eylemlerinin yoğun biçimde kullanıldığ öğretim süreçlerinde alternatif yöntem ve tekniklerin kullanımı da tercih edilmemektedir. 
- K1: Günümüz eğitim sistemi öğrencilerin yetenek ve becerilerini hiç hesaba katmayan, ezbere yönelik ve öğrenciyi düşündürmeyen bir sistemdir.

- K14: Sınıflar öğrenci merkezli olmalıdır. Öğretmen sınıfta hâkimdir ve öğrenci ancak kısıtlı zamanlarda devreye girebilmektedir.

- K15: Bu sistemde öğrenci amacına ulaşmak için ezberlemek zorunda yani anlamlı öğrenme yok bilgiyi depolama var.

- K35: Teorik dersler azaltılip onun yerine sosyal aktiviteler ve zekâ oyunlarının oynatılacağı dersler daha verimli olacaktır. Dersler videolarla, filmlerle, uygulamalarla zenginleştirilmelidir.

Böyle bir eğitim sistemi tek kanatla uçmaya çalışan bir kuşa benzetilebilir. Yani eğitim sistemi bireylerin yalnızca bilişsel güç ve yetilerine odaklanmaktadır. Bu bilişsel yetilerden de ezber yaparak depolayabilme yani bir bilgiyi aynı haliyle hatırlayabilme önemsenmektedir. Yalnızca Bloom taksonomisinin bilgi basamağında becerilere sahip olma eğitim sistemi açısından tercih edilir durumdadır. Hâlbuki eğitimin amaç ve işlevlerine dönük çözümlemeler yapan birçok felsefe, eğitimin bütünsellik ilkesine uygun oluşunu önemli görmüşlerdir. Bu ilke uyarınca ideal bir eğitim sistemi bireyin bilişsel, duyuşsal ve psikomotor yetilerini dengeli biçimde geliştirmelidir. Dengeli gelişimi sağlamada yetersizlik gösteren sistemler, bir süre sonra toplumda bir dizi sorunun ortaya çıkmasına zemin hazırlamış olacaktır. Araştırmaya katılan öğretmen adayları da özellikle eğitimin bu üç alanda dengeli bir gelişimi sağlamada problem yaşadığını düşünmektedirler. Öğretmen adaylarının görüşleri incelendiğinde eğitimin sorgulama becerisini, duygu ve özbakım becerilerini, araştırma becerisini, bilgiyi uygulama becerisini, merak duygusunu ve bedensel becerileri yeteri kadar geliştirmediğini düşündükleri söylenebilir. Özellikle bilgi aktarmaya ve ezbere dönük bir eğitimin bilgiyi kendine mal etme, bilginin bileşenlerini ve diğer bilgi birimleriyle ilişkisini belirleme, üretme, özgün bir ürün oluşturma gibi üst düzey bilişsel becerileri kazandırmada da kötü bir karneye sahip olduğu düşünülmektedir. Günümüzde özellikle yapılandırmacı bilgi edinme kuramının da temel ilkelerinden biri olan bilgiyi bir problem bağlamında kullanma becerisinin, teorik dersleri merkeze alan bir sistemle gerçekleştirilemeyeceği ifade edilebilir.

- K16: Yapılandırmacı eğitim anlayışına uygun müfredatlar hazırlanırken öğretmenler bu formattan uzak kalmakta ve kendini sadece 
bilgiyi vermekle yükümlü görmektedir. Bu nedenle öğrenciler sorgulamaktan, araştırmaktan, düşünmekten uzak kalmaktadır.

- K31: Eğitimde akademik başarının çok ön plana çıkası ve yaşamsal başarının bir kenara itilmesi de başka bir sorundur.

Bunun yanı sıra çağdaş eğitim felsefelerinin ve bilgi kuramlarının ortaya koymuş olduğu teorinin aksine ezberci bir eğitim sistemi bilgi, konu, disiplin ve öğretmen merkezli bir öğretim sürecini doğurmaktadır. Buna karşın günümüz eğitim sistemleri, öğrenme sürecinin merkezinde öğrencinin kendisinin bulunması gerektiğini ssrarlı biçimde savunmaktadır. Geleneksel öğretimin aksine günümüz eğitim sistemi nesnel bilginin yerini öznel bilginin ve çoklu doğruların aldığını belirtmektedir. Ezberci eğitim sistemi bu yolla anlamlı öğrenmeyi engellemekte ve bireyin bilgiyi yalnızca gireceği sınav veya alacağı nota göre değerlendirdiği bir anlayışı doğurmaktadır. Dolayısıyla bilgiye ve eğitime bakış aşınmakta ve birey eğitime pragmatist bir şekilde ile yaklaşmaktadır. Bu tarz bir eğitim sisteminin kişisel gelişimi gerçekleştirmediği de öğretmen adayları tarafından ifade edilmiştir. Ayrıca bireyin sosyal, toplumsal, psikolojik vb. yönleri ve yansımaları da bu sistem tarafından ihmal edilmektedir.

- K23: Eğitim sisteminin büyük sorunlarında biri bir işin bilgisini öğretmekte iyi olmakla birlikte bireyi toplum için faydalı hale getirememesidir. Bunun sebebi de sistemin toplumsal ve sosyal boyutu göz önüne almamasıdır.

Bu tema altında öğretmen adayları sınava yönelik sistemin bir problem olduğuna da değinmişlerdir. Birey sınav odaklı hareket ettiği öğretim sürecinde, tüm eğitsel öğeleri sınav için ne kadar önemli ve yararlı olduğuna bakarak derecelendirmektedir. Bu nedenle eğitim sistemi entelektüel becerilerden daha çok sınava yönelik becerileri kazandırmada daha etkili olmaktadır. Çünkü öğrencilerin edinmek için asıl motive olduğu beceriler sınav veya test başarısını artıran becerilerdir. Bu sınav ve test yapılarının bilgiyi ölçen bir özellik göstermesi temayı oluşturan ezberci eğitimi sisteminin güçlenerek sistemdeki varlığını korumasına zemin hazırlamaktadır. Yalnızca sistem değil öğrenciler, veliler, öğretmenler, okul idarecileri ve sistemin tepesindekiler performans göstergesi olarak yalnızca bilişsel parametrelere odaklanmaktadır. Ölçüt sınav başarısı olduğunda sistemde başka yönleriyle ön plana çıkan bireylerin bu özellikleri bir başarı olarak nitelendirilmemekte ve açıkçası kıymetsiz görülmektedir. Bu durum bireysel farklılıkları hiçe 
sayan ve her bireyin sınav sonucuna göre sinıflandırıldığı bir durumu ortaya çıkarmıştır ve bu durum seçmeye yönelik eylemler devam ettikçe geçerliliğini korumaya devam edecektir.

- K26: Çocukların anlama, kavrama, akıl yürütme, problem çözme, hayal gücünü geliştirme gibi yeteneklerini geliştirmeyi amaçlaması gereken eğitim sadece test sınavlarında doğru cevabı hatırlama yeteneğini geliştirmekle sinırlı kaldı.

\section{Ĕ̈itimin Bireyin Gelişimini Esas Almaması}

Öğretmen adaylarının görüşlerine göre Türk eğitim sisteminin sorunlarından biri de bireyin gelişimini esas almamasıdır. Bu temada en çok öne çıkan sorun alanı, eğitim sisteminin bireysel farklılıkları dikkate alıp buna yönelik bir yönlendirme yapamamasıdır. Eğitimin çoklu zeka türü, öğrenme hızı, motivasyon, öğrenme ihtiyacı, öğrenme stili, zeka, ilgi ve meta biliş gibi bireysel değişkenleri öğretimi düzenlerken dikkate almadığı 48 kez öğretmen adayları tarafından dile getirilmiştir. Yine insanların özellikle meslek seçiminde yeteneklerine göre yönlendirilememesi de eğitim sisteminin eksikliklerinden biri olarak belirtilmiştir. Bu durum da öğretim alan bireylerin yeteneklerine göre değil de pragmatist bir bakışa uygun şekilde geliri yüksek mesleklere yönelmesi sonucunu doğurmaktadır. Ayrıca eğitim sisteminin mesleki yönlendirmeyi geç yapması da öğretmen adayları tarafından bir sorun olarak dile getirilmiştir.

- K56: Başka bir sorunumuz ise insanların yeteneklerine uygun mesleklere değil çevre baskısıyla popüler mesleklere yönlendirilmesi.

- K59: Ülkemizde uygulanan eğitim sistemiyle öğrenciler aldıkları s1nav puanları baz alınarak meslek seçimlerine mecbur bırakılıyor. Bunun yerine öğrenciler hedefleri doğrultusunda yönlendirilmelidir ki sevdikleri mesleği yapsınlar.

- K36: Çocukların küçük yaşta hangi yönde yeteneği ve ilgisi olduğu genel olarak belirlense ve öğrenciye buna göre eğitim verilse bu öğrenci hem daha mutlu olur hem de millete katkısı daha büyük olur diye düşünüyorum.

Bu tema altında eğitim sisteminin yalnızca sözel ve de özellikle sayısal zekâyı makbul gören bir anlayışa sahip olması ve bu anlayış uyarınca birtakım bireyleri değersiz görerek gözden çıkarılabilir olarak değerlendirmesi 
önemli problemlerden biri olarak belirtilmiştir. Sınav/test başarısını önceleyen eğitim sistemi rekabetçi bir yapı doğurmaktadır. Başarıyı yalnızca belli dönemlerde yapılan kısa süreli yoklamalardan ibaret görmek öğrencinin tüm motivasyonunun iyi puan almaya yönelmesine neden olmaktadır. Bu da eğitimin özünü bozan bir etki yaparak, eğitimin önemli amaçlarından biri olan "terbiye" nin tamamen ihmal edilmesine, "talim" in ise belli kalıplara hapsolmasına sebebiyet vermektedir. Bir kısım öğretmen adayı rekabetçi eğitim sisteminin eşitsizlikleri doğurduğunu ve bunun yine eğitimin doğasina aykırı olduğunu söylemişlerdir.

- K22: Her insanın kendisine göre bir becerisi vardır. Eğer öğrenciler baskıcı bir eğitimin içinde olmasa ve matematik yeteneği olan bir bireye çok zeki olarak bakılmasa çevremizde çok daha yaratıcı, mutlu ve huzurlu bireyler olabilirdi.

Bununla birlikte bu temada zorunlu eğitimin esnek olmayan ve bireyin tercihlerine dönük seçimler yapmasına imkân tanımayan yapısı da bir problem alanı olarak ifade edilmiştir. Bizzat zorunlu eğitimin varlığ bireyin ögretmen adaylarının bir kısmı tarafından bireyselliği ihlal eden bir olgu olarak tanımlanmıştır. Bununla birlikte eğitme dair alınan kararlarda ve yapılan düzenlemelerinde, öğrencinin özelliklerinin göz önüne alınmaması önemli bir problemdir. Bu bağlamda eğitim sistemi bireyi beşer olarak değil de yığının bir birimlik bir elemanı olarak görmektedir. Bu da öğrencilerin sistem tarafından değer görmediği şeklinde bir algıya sahip olmasına ve eğitimi özgürlüklerini kısıtlayıcı bir unsur olarak değerlendirmelerine neden olmaktadır. Yani sonuç olarak eğitim bireyi bir birey olarak kabul edip değer vermemektedir.

- K21: Şu anki bulunan sistemde öğretmen öğrenciyi kendi doğruları doğrultusunda eğitiyor. Öğrencilerin durumları göz önüne alınmaksızın herkesin aynı bilgiyi alması aynı şeyi yapması bekleniyor fakat öğrencilerin hepsi bir değiller ki. Bu nedenle öğrenciler yarım yamalak öğrenerek mezun oluyorlar.

\section{Öğretmene İlişkin Süreçler ve Politikalar}

Öğretmen adayları görüşlerini belirtirken 42 kez öğretmenlik mesleğine ve öğretmenlere dair süreç ve politikaların eğitim sistemi açısından sorun oluşturduğunu dile getirmişlerdir. Öğretmen adaylarının büyük kısmı öğret- 
men yetiştirme ve seçme sisteminin işlevsiz olduğunu belirtmişlerdir. Özellikle öğretmen yetiştirme sistemlerinin öğretmen adaylarına öğretmenliğe dair tüm becerileri kazandırmada yetersiz olduğunu ve öğretmen yetiştirme sürecinde uygulama imkânının kısıtlı olduğuna değinmişlerdir. Katılımcılar öğretmen yetiştirme sisteminin bir öğretmen adayını mesleği gerçekleştirmesi olası tüm durumlara hazırlayamadığını düşünmektedirler. Bunun yanı sıra öğretmenliğe başladıktan sonraki hizmet içi eğitim süreçlerinin de öğretmen niteliğini artırmada etkili olmadığı adaylar tarafından belirtilmektedir. Öğretmen seçme sürecinin ise yalnızca yapılan bir bilişsel sınavdan ibaret oluşu, katılımcılar tarafından problem olarak değerlendirilmiştir. Sadece bilişsel bir sınavın sonuçları ile karmaşı birçok beceriye sahip olmanın gerekli olduğu öğretmenlik mesleğine seçim yapılmasının, isabetsiz kararlar vermeye yol açtı̆̆ katılımcılar tarafından düşünülmektedir. Bunun yerine öğretmen seçiminin bu çoklu becerileri ölçebilecek bir yapıya kavuşturulması gerekmektedir.

- K2: YKS, AYT, KPSS gibi sınavlar mantıksal zekâyı ölçmektedir ancak onun dişında hiçbir zekâ türünü ve kabiliyetini bence ölçemez. $\mathrm{Bu}$ tarz seçme sınavlarının yanında öğretmenlik kabiliyet ve isteğini ölçen bir sistem geliştirilmelidir.

- K10: Öğretmen seçme ve yetiştirme sisteminin niteliğini artırmak eğitimle ilgili birçok sorunun çözümünü kolaylaştıracaktır düşünüyorum.

- K18: Bana göre problemlerin en büyüğ̈̈ öğretmenlerin kâğıt üzerindeki bir sınav sonucu seçilmesidir. Bu yolla seçilen öğretmenlerin içinde psikolojik sorunlu, çocukları sevmeyen ve onlara adil davranamayan kişiler de bulunabiliyor. Bu sistemin değişmesi gerekir.

Araştırmaya katılan öğretmen adayları sistemde görev yapan mevcut öğretmenlerin niteliğinin de bir problem alanı olduğunu düşünmektedirler. Bu görüşlerini dile getirirken mevcut öğretmenlerin çağdaş felsefelerin ilkelerine ve bilgi ve iletişim teknolojilerindeki gelişmelere adapte olamadiklarına sıklıkla dikkat çekmişlerdir. Dolayısı ile öğretmenler öğrenme ortamlarını bireysel farklılıklara göre düzenlemede, farklı yöntem ve teknikleri sınıf ortamında işe koşmada ve çağdaş felsefelerin kendilerine yüklemiş olduğu rehber rolünü gerçekleştirmede zafiyet göstermektedirler. Bunun yanı sıra öğretmen seçme sisteminin yetersizliği de nitelikli öğretmenlerin belirlenmesini engellemektedir. Bir kısım öğretmenin kendini yenileme çabası içeri- 
sinde olmaması veya sistemin yapısından dolayı gelişememeleri de bu durumu doğuran etmenlerden biridir.

- K13: Eğitimin temel sorunlarından biri de eğitim kadrolarında yer alan eğitimci kişilerin bir nevi biz öğretmenlerin yeterli donanıma sahip olmamızdır. Birçok öğretmenin teknolojik gelişmeleri takip etmesi çok önemlidir ama bu durum bilgisayar öğretmenliğinde daha bir önemlidir. Ancak ben bu niteliğin yeterli olmadığını gözlemliyorum.

Bazı katılımcılar ise öğretmenlerin sistemsel kararlarda ve program geliştirme sürecindeki pasif rolleri nedeniyle motivasyonlarının ve özerkliklerinin düşük olduğunu ifade etmiştir. Merkezden gelen kararları ve programları katı bir anlayışla uygulama konumunda olan öğretmenlerin herhangi bir inisiyatiflerinin olmaması nitelikli bir öğretim hizmetini engellemektedir. Bu bağlamda öğretmen etkenlikleri yani kendi mesleki gelişimlerini yönetme ve meslektaşların gelişimine de katkı sağlama beceri ve inisiyatifleri de düşük olmaktadır.

- K21: Günümüz eğitim sistemi öğretmenlere sistemin işlemiş olduğu merkezi programı öğrenciye direkt aktarma görevi vermiştir. Kademe fark etmeksizin bu rolün dışına çıkan öğretmen yok denecek kadar az bence. Öğrenciye bir şey katmak için çırpınan öğretmenlerin sayısı artmalıdır.

Katılımclardan bir kısmı ise öğretmen atama sistemindeki yanlışların Türk eğitim sisteminin sorunlarından biri olduğunu ifade etmektedir. Özellikle ülkenin belli bölgelerinde yetersiz sayıda öğretmenin bulunması ve yine bu bölgelerde sık öğretmen değişimi önemli bir problemdir. Sistemi yönlendirenler bu konuya dair son yıllarda birtakım önlemler almaya çalışsalar da bölgeler arasındaki bu eşitsiz durum halen devam etmektedir. Yine aynı durum bir ildeki şehir merkezi ve kırsal bölgeler arasında da görülmektedir. Öğretmen atama sisteminin bu zafiyeti öğretmensiz okullar, taşımalı eğitim veya birleştirilmiş sınıflar gibi alt problemlerin ortaya çıkmasına neden olmaktadır.

- K8: Yeni atananların doğu bölgesinde görev yapması ve henüz bir bilgi birikimi ve tecrübesi olmadan bunun gerçekleşmesi bir haksızlık olarak değerlendirilebilir. 
- K44: Eğitimin sorunlarında biri de doğudaki öğrencilerin neredeyse üçte birinin her yıl öğretmeninin değişmesi. Bu öğrencilerin temel becerileri bile kazanması mümkün olmuyor bu yüzden.

Katılımcıların bir kısmı ise öğretmenliğin toplum içindeki statüsünün problemli olduğunu ve bu statünün yükseltilmesi için eğitim yöneticilerinin gerekli düzenlemeleri yapma performanslarının yeterli olmadığını belirtmiştir. Bu düzenlemeler arasında ücret artırımı, öğretmenin güvenliğini sağlama, eğitsel kararlarda daha fazla inisiyatif verme veya çalışma koşullarının iyileştirilmesi gibi hususların devreye sokulması gerektiği savunulmaktadır.

- K43: Öğretmenlerin toplumdaki yeri bu kadar önemliyken bu kadar az ücret almaları mantı̆̆a sığmıyor. Ekonomik özgürlüğü olmayan bir birey meslekten soğuyacaktır veya dersini isteksiz biçimde aktaracaktır.

\section{Ĕ̈itimin İşlevi}

Öğretmen adayları Türk eğitiminin sorunlarına ilişkin görüşlerini ifade ederken 35 kez eğitimin işlevine dair sorunlarına atıfta bulunmuşlardır. Bu başlık altında öğretmen adaylarının büyük çoğunluğu eğitimin hayattan kopuk oluşuna değinmişlerdir. Öğretimin temel ilkelerinden biri olan hayatilik ilkesinin eğitim sistemi tarafından yeterli biçimde sağlanamaması öğretmen adayları tarafından sistemin temel sorunlarından biri olarak yorumlanmıştır. Katılımcılar, eğitim sisteminin, öğretimin ve programların gerçek yaşam göz önüne alınmadan oluşturulduğunu düşünmektedirler. Bunun yanı sıra eğitimin toplumun gerçeklerinden uzak oluşu da öğretmen adayları tarafından dile getirilen bir husustur.

- K1: Günümüz eğitim sistemi daha çok teoride kalmış bulunmaktadır. Hâlbuki eğitim sistemimiz gerek içerik gerekse yöntemler bakımından topluma yakın olmalıdır. Sistem toplumdan kopuk olduğu için gençler okul sonrası yaşama uyum sağlayamamaktadır.

- K15: Öğrenciler matematik, fizik, kimya vb. birçok ders görüyor. Bu derslerin hepsi olmasa da bazıları günlük hayattan çok uzak olup vakit kaybından öteye gidemiyor. Öğrenciler öğrendiğini günlük hayatta kullanmayınca da unutuluyor. 
Bu tema altında öğretmen adayları eğitimin yoğun bir şekilde bireyin yaşamında ihtiyaç duyduğu becerileri ve yüzyılın gerektirdiği yetileri kazandırmadığını ifade etmişlerdir. Eğitimin temel becerileri kazandırmada bile yetersiz oluşunun yanı sıra iletişim, düşünme becerileri, inovasyon, üretim, teknoloji okuryazarlığ ve işbirlikli çalışma gibi becerileri de kazandırmada yeterli performansı göstermediğini dile getirmişlerdir.

K2: Yani şöyle, akademik başarı gerekli olmakla birlikte yaşamsal başarı da gerekli. Matematik problemi çözmek kadar kendini iyi ifade edebilme ve etkili iletişim de önemli.

K35: Derslerin birçoğu öğrenciye bir şey sorgulatmıyor. Yani öğrenci acaba neden böyle demiyor, hazır bilgiye alışmış. Sonra da düşünme becerileri önemli deniyor. $\mathrm{O}$ zaman öğrenciyi düşünmeye sevk edecek bir sistemin olmasi gerekmez mi?

Öğretmen adayları eğitimin işlevine ilişkin sorunlara eğitimin gerçek yaşamda kullanılmayacak, gerekli olmayan, işlevini kaybetmiş bilgiler öğretmesini ve sistemde birçok gereksiz derslerin bulunmasını da dâhil etmişlerdir. Öğrencilerin okulda günlük hayatta kullanmayacakları bilgileri depolamak durumunda kalmaları, süreç içerisinde okulla hayat arasında bir duvar oluşmasına ve öğrencinin eğitimin anlamını sorgulamaya başlamasına neden olmaktadır. Bu bağlamda eğitim dört duvar arasına sıkışmakta; öğrenciler öğrendiklerini yaşamlarına ve gerçek hayatta karşılaştıkları problemlere yansitmakta güçlük çekmektedirler.

- K6: Ben açıkçası sistemdeki teorik derslerin birçoğunun gereksiz olduğunu düşünüyorum. Bu öğrencinin omzunda ağır bir yük oluşturuyor. Teorik derslerin yerine spor, sosyal aktivite gibi dersler gelmeli ve birey gerçek hayata hazırlanmalı.

- K25: Bence eğitim sistemimizin en büyük problemlerinden biri dört duvara sıkıştırılmış belli saatlerden oluşan bir eğitim verilmesidir. Dersler de genellikle belirlenmiş zorunlu derslerden oluşmakta. Yıllardır değişmeyen bu derslerin çoğu öğrencilere anlamsız geliyor. Derslerin bir kısmı için neden bunu görüyoruz diye soruyorlar, hepimiz sorduk.

$\mathrm{Bu}$ tema altında öğretmen adayları eğitim sisteminin birtakım temel amaçlarını gerçekleştirmekte de zafiyet gösterdiğini belirtmektedirler. Öğretmen adayları genel anlamda müfredatın yetersiz olduğunu, eğitim sisteminin niteliğinin düşük olduğunu, eğitim sisteminin ana dil ve yabancı dil 
öğretiminde başarılı olmadığını ve öğrencilerin etüt merkezi, kurs gibi alternatif seçeneklere başvurmak durumunda kaldıklarını ifade etmişlerdir.

- K8: Eğitim sisteminin niteliği de düşük. Mesela fakültede derslerde PISA sonuçlarını konuşuyoruz hep. Bence bu en önemli göstergelerden biri. Tamam, tek başına her şey değil ama öğrenciler geleceğe ne kadar hazır ciddi bir fikir veriyor.

- K13: Gelişmiş ülkelerin müfredatlarına bakıldığı zaman bizimki tamamen bir enkaz. Eskimiş bilgileri öğrencilere ezberletmekten öteye geçmeliyiz.

\section{Ĕ̆itim Sisteminin İstikrarsız Oluşu}

Öğretmen adayları eğitim sistemindeki politikaların sürekli değiştiğini ve sistemin istikrarsız bir yapıya sahip olduğunu $27 \mathrm{kez}$ ifade etmişlerdir. Eğitim sisteminde özellikle kademeler arası geçiş, sınav gibi uygulamalarda bir önceki uygulamanın sonuçların beklemeden yapılan köklü değişimlerin sistemin niteliğini düşüren bir etki yaptığını belirtmişlerdir. Bu noktada sistemin geçmiş birikimlerinden dersler çıarma yetisinin düşük oluşu da bir problem alanı olarak dile getirilmiştir.

- K40: Bu sorun ülkenin sürekli gündemindeki bir konudur. En çok da sınav sistemleri değişiyor ülkemizde. Tam bir öğrenci artık geleceğimi bu sisteme göre planlayım dediği anda pat diye sistem değişiyor ve o öğrenciyi artık kaybediyoruz. İstikrar eğitim sistemi için şart bence.

- K45: Günümüz eğitim sisteminin sorunlarından biri de sürekli değişen sınav sistemlerdir. Bu değişimler her öğrencinin tedirgin olmasına ve umutsuzluğa kapılmasına neden olmaktadır. Ben bu değişikliklerin birçok öğrencinin okuma hevesini yıktığını düşünüyorum. Bu belirsizlikler ile daha ne kadar yürüyebiliriz bilmiyorum.

\section{Fiziki Altyapı, Donanım Ve Kaynak Eksikliği}

Araştırmaya katılan öğretmen adayları 20 kez Türk eğitim sistemindeki fiziki alt yapı, donanım ve kaynak eksikliğinin bir problem alanı olduğunu belirtmişlerdir. Bu tema altında öğretmen adayları eğitime ayrılan bütçenin yetersiz olduğunu ifade etmişlerdir. Taşımalı eğitim, kalabalık sınıflar, ikili öğretim gibi unsurların eğitim sistemindeki kaynak eksikliğini kanıtlayan olgular olduğu katılımcılar tarafından dile getirilmiştir. Öğretmen adayları 
ayrıca birçok okulda laboratuvar, okul bahçesi, sosyal alanlar ile sınıfların ve materyallerin ihtiyaçları karşılayacak seviyede olmadığını belirtmişlerdir.

K26: Ülkemizde eğitim sistemi için gerekli bütçe ayrılmadığından sistem olumsuz etkileniyor. İstenen eğitim kalitesi yakalanamıyor. Okullarda olması gereken malzemeler, araçlar, gereçler olmadığı için aksaklıklar yaşanıyor ve bu da eğitimli insan sayısını düşürüyor.

- K8: Eğitimdeki imkânların yetersizliği taşımalı eğitim uygulamasını yaygınlaştırdı. Bu durum bence öğrenciler için zor ve eğitimi bence olumsuz etkiliyor.

\section{Fırsat Eşitliği}

Öğretmen adayları fırsat eşitliği sağlayamama durumunu Türk eğitim sisteminin sorunlarından biri olarak göstermişlerdir. Öğretmen adayları $15 \mathrm{kez}$ eğitim sisteminin fursat ve imkân eşitliğinden uzak bir hizmet verdiğini ifade etmişlerdir. Öğretmen adayları özellikle bu eşitsizliğin sosyoekonomik düzey değişkeninin etkisi sonucu ortaya çıktığını söylemektedir. Eğitim hizmetinden yararlanabilme düzeyinin öğrencinin sosyoekonomik düzeyi ile yakından ilişkili olduğu katılımcılar tarafından belirtilmiştir. Sosyoekonomik düzeyi yüksek ailelerden gelen öğrencilerin, çeşitliliğe sahip, nitelikli ve üst düzey becerileri geliştirmeye dönük bir öğretim sürecine katılımlarının daha olası olduğu katılımcıların görüşleri arasındadır.

- K36: Eğitimin verildiği ortamın imkânları önemli. Örneğin köyde yaşayan öğrenci teorik olarak dersi görüp geçiyor ama şehirde yerine göre etkinlikler veya uygulamalarla destekleniyor. Bu da öğrenci arasında fark yaşanmasina neden oluyor.

- K43: Maddi durumda iyi okulda okusun, iyi eğitim alsın mantığı bence büyük bir problem. Elit aile çocukları mesela özel okullara gidiyorlar. Eğitimleri daha önemseniyor ve üzerlerine düşülüyor. Şimdi sormak istiyorum madem bütün çocuklar eşit ve sosyal devlet diyoruz. O zaman neden çocuklar aynı imkânlara ulaşamıyorlar ve aynı seviyede bir eğitim alamiyorlar.

Bazı katılımcılar fırsat eşitliği temasına bir ülkenin veya bir ilin farklı bölgeleri arasındaki farklılık perspektifinden yaklaşmışlardır. Özellikle ülkemizdeki bazı bölgeler arasında ve de bir ildeki kentsel ve kırsal yerleşim yerleri arasında eğitim niteliği açısından bir eşitsizlik oluştuğunu savun- 
maktadırlar. Hatta bu durumun bir ilden başka bir ile veya özellikle bir il içerisinde köyden kente göç olgusunun nedenlerinden biri olduğu katılımc1lar tarafından ifade edilmektedir. Yani ebeveynler, çocukları daha nitelikli bir eğitim alabilsin diye köyden veya ilçeden ayrılıp il merkezine yerleşebilmektedir.

- K2: Ülkemizde bölgeler arası ve kırsal kesimlerden kentlere sürekli göçler yaşanıyor. Bu nedenle köyde okullar kapanırken kentte okullar yetersiz kaliyor.

- K3: Kısaca tanımlamak gerekirse bir örnekle kısal kesimde yaşayan insanların daha iyi bir eğitim alması için şehir merkezlerine taşınması sonucu kırsal kesimdeki okullar kapanıyor. Böyle olunca ya taşımalı eğitim ya da okulu bırakma ortaya çıkıyor. Sonuç olarak kırsal kesimde yaşayan insanların eğitim seviyesi düşüyor. Şehir merkezinde de sınıflar kalabalıklaşıyor. Öğretmenler 35-40 kişilik sınıflarda ders anlatmaya çalışıyor ve her bir öğrenci ile ilgilenemiyor.

Bazı katılımcılar da ülkemizde farklı kademelerde bulunan okul türlerinin eğitimin niteliği açısından bir eşitsizliğe neden olduğunu belirtmişlerdir. Özellikle lise kademesinde bu durumun belirgin bir hale dönüştüğünü ve nitelikli liselerin belirlenmesi sürecinin bu durumu daha yerleşik hale getirdiğini ifade etmişlerdir.

- K17: Ortaöğretimin niteliğini güçlendirmek ve okullar arasındaki kalite farkını azaltmaya odaklanmak gerekiyor. Nitelikli-niteliksiz lise ayrımı daha baştan öğrenci için motivasyon kırıcı. Bence tüm okulları nitelikli hale getirmek lazım. Bir meslek lisesi de bir fen lisesi kadar nitelikli olmalı.

\section{Ĕ̆itimin Öz Farkındalık Kazandırmadaki Eksikliği}

Öğretmen adaylarına göre eğitimi sisteminin eksikliklerinden biri de bireye kendisi ve çevresi hakkında bir farkındalık kazandırma hususunda ortaya çıkmaktadır. Eğitimin önemli işlevlerinden biri bireyin kapasitesini ortaya çıkartıp bireyin gelişimini sağlamaktır. Bireysel gelişim sürecinde bireyin özyeterlik, öz farkındalık, özgüven ve meta biliş gibi özelliklerinin geliştirilmesi kritik görülmektedir. Bu bağlamda birey eğitim sonucunda kendisine dönük farkındalık kazanmalı ve bunun sonucunda yaşamını sağlıklı, dengeli ve başarılı bir şekilde sürdürebilmelidir. Bu amaç doğrultusunda 
eğitimin bireye disiplinli olma, duyguların kontrol etme, isabetli hedefler belirleme, özsaygı sahibi olma gibi özellikleri kazandırması önemlidir. Araştırmaya katılan öğretmen adayları, Türk eğitim sisteminin bireye kendisi hakkında bir farkındalık kazandırmadığını belirtmekte ve bunun temel nedeninin bireyi merkeze almayan ezberci eğitim sistemi olduğunu ifade etmektedir. Bu tarz bir eğitim bireye bir iç disiplin kazandırmakta da yetersiz kalmaktadır.

- K1: Kendine güveni olmayan, boşluk içinde, değerlerini yitirmiş, endişeli, yaşamdan kopuk ve kendine ve ulusuna yabanı gençler hiç iç açıcı gözükmüyor değil mi? Ama bu onların istekleri sonucu değildir. Uygulanmakta olan eğitim modelimiz bu tür bireylerin oluşmasını hazırlamiştır.

- K3: Çocuklarımızın duygusal eğitimi onlara akılcı amaçlar belirleyip o amaçlara ulaşma disiplin ve isteği kazandırmıyor. Çocuklarımız kendine güvenen, hayalleri ve umutları olan bireyler olmak yerine depresif, asosyal ve mutsuz bireyler olma yolunda hizla ilerlemektedir.

- K14: Bizim eğitim sistemimizde öğrenci dış disipline uyar ve bu nedenle de iç disiplini yeteri kadar gelişmez. İyi de bu çocuğun başında devamlı öğretmen bulunmayacak ki. O zaman işte çocuk devamlı bir yetişkinin talimatlarına ihtiyaç duyacaktır.

Birey böyle bir ekosistemde kendini tanımamakta ve akılcı amaçlar belirlemede başarısız olmaktadır. Birçok öğrenci, öğrenme ve ders çalışma stratejilerine dönük düşük farkındalıkları neticesinde birtakım disiplinlerde sürekli tekrar eden başarısızlıklar yaşamakta ancak bunu bilişsel olarak yetersiz oluşuna bağlamaktadır. Dolayısıyla eğitim öğrenciler için asli amacını yitirmekte ve öğrenciler özgüven eksikliği yaşamaktadır; yani başarmaya dönük inançları gün geçtikçe azalmaktadır. Ayrıca birey kendi yeteneklerinin farkına varamadığı için bölüm, okul veya meslek seçimi gibi kritik kararları verirken isabetli seçimler yapamamakta ve bu da mutsuz bir yaşantiya neden olabilmektedir. Bu durumun üstesinden gelebilmek bireysel farklıkları önemseyen ve çoklu öğeler içeren program ve öğretim süreçleriyle mümkün olabilecektir.

- K22: Günümüz eğitim sisteminin en önemli problemlerinden biri öğrencilerdeki özgüven eksikliğidir. Bunu yaşamayan öğrenci çok azdır. Dışarıdan gelen baskı yüzünden yarış atına dönen öğrenci bir 
süre sonra başarısızlık korkusu ile ağır stres yaşamaya başlamaktadir.

Katılımcılardan bazıları ise öğrencinin kendisinin merkeze alınmadığı bir eğitim sistemine isteksiz yaklaştığını ve genel olarak öğrencilerin eğitime dair motivasyonlarının düşük olduğunu söylemiştir. Öğrenciler bireysel farklılıklarını dikkate almayan ve esnek olmayan bir eğitim sistemine yalnızca belirli zorunluklar uyarınca katılım göstermektedir. Ülkemizde öğretim kademelerini tamamlamanin ve bu süreci temsil eden semboller olan diploma, sertifika, karne gibi unsurların bireyin toplumsal sınıfını belirlemede önemli bir araç olması, öğrencilerin eğitimine devamını sağlayan temel unsur olmaktadır. Bunun yanı sıra zorunlu eğitim olgusu ile öğrencilerin ailelerinden ve çevrelerinden gelen baskılar da öğrencinin eğitime devamını sağlamaktadır. Ancak sistem içinde bu unsurların dışında öğretime entelektüel bir anlam yükleyen ve eğitim almanın kendisi için anlamlı olduğunu düşünen öğrenci sayısı sınırlı kalmaktadır.

- K32: Eğitim sisteminin bir diğer en büyük problemi öğrencilerin ilgisizliği, isteksizliğidir. Öğrenci düzenli ders çalışmıyor, dersle ilgili birçok sorumluluğu yerine getirmiyor. Ama kalma olmaynnca dersleri sıkıntısız geçiyor. Lisansta bile birçok öğrenci çok az çabayla geçiyor. Hepsinin aklında diploma var başka bir istekleri de yok.

Bazı katılımcılar ise eğitim sisteminin varoluşçu ilkelere dayalı değişiklikleri uygulamaya aktarma sürecinde olumlu adımlar attığını ancak bu adımların bir kısmının amaç kaymasına uğradığını düşünmektedir. Bu düşüncelerine örnek olarak da öğrenci merkezli eğitim olgusunu vermektedirler. Çağdaş felsefelerin ilkelerini öğretim sürecine yansitma noktasında çaba gösteren eğitim sistemi bu süreçte öğrencilere verilen özgürlüğü abartılı bir noktaya taşımıştır. Böylece birey kendisini her şeyin ölçüsü olarak görmeye başlamış ve bir bakıma yine iç disiplin kazanma noktasında zafiyet yaşamıştır. Yani kendisine dönük farkındalığını bu sefer üzerindeki baskı unsurundan dolayı değil de özgürlük unsurundan dolayı olgunlaştıramamıştır. Bu durumun sonuçları olarak okullarda disiplinin sağlanmasında yaşanan zorluklar, öğrencilerin derse veya öğrenmeye sevk edilmesinin güçleşmesi, eğitim dışı birtakım amaç, süreç ve unsurların sistemde öğretimden daha etkili olması ve okul güvenliğinin tehlikeye girmesi olmuştur. Yani bu olgu da eğitimi anlamını yitirmesine neden olmuştur. 
K33: Eğitime farklı bir anlayış geldi. Öğrencilere sert, zorlu davranmak yerine onların içindeki cevheri keşfetmek. Tamam, yanlış bir yaklaşım değil ama vur deyince öldürmüşler gibi geliyor bana. Çocuklara ancak yetişkinlerin baş edebileceği özgürlükler ve seçenekler verirseniz yani ona yetişkin gibi davranırsanız sonuçları bugünkü gibi olumsuz olur.

K55: Okullarda özgürlükler çok fazla artış gösterdi. Örneğin serbest kıyafet uygulaması ile öğrenci bir okula mensup olmak, aidiyet ve sorumluluk hissi taşımaktan uzaklaştı. Bu bence ipin koptuğu yer oldu ve özgürlükler arttı ve önü alınamayacak noktalara vardı.

Bazı öğretmen adayları ise okullarda verilen ve öğrencinin öz farkındalık kazanmasında etkili olması beklenen rehberlik ve psikolojik danışmanlık hizmetinin yetersiz ve işlevini gerçekleştirememekte olduğunu ifade etmişlerdir. Rehberlik faaliyetleri ögrencinin kendini tanıması, yeteneklerini fark etmesi, öğretimsel ve mesleki yönelimlerini belirlemesi süreçlerinde önemli bir hizmet olarak karşımıza çıkmaktadır. Bu hizmetin niteliğinin düşük olması öğrencilerin bu alanlardaki farkındalı̆̆ının ve karşılaştıkları kriz durumları ile baş etme yetilerinin düşük olmasına zemin hazırlamaktadır. Dolayısı ile bu hizmete ilişkin düzenlemeleri eğitim kurumları tarafından nitelikli biçimde yürütülmesine dönük tedbirler alınmalıdır.

- K8: Eğitimimizdeki problemlerden biri de rehberlik problemidir. Çoğu öğrenci ne zaman rehberlik servislerine başvuracağını bilmemektedir. Genellikle sorun çok büyüdükten ve geç kalındıktan sonra rehberlik servislerine başvurulmakta. Başta rehber öğretmenlerin sayısı da yetersiz ve rehberlik kırk dakikalık konuşmadan ibaret bir şey olmamalıdır.

\section{Değer Eğitimi}

Öğretmen adayları Türk eğitim sisteminin değer aktarımı veya eğitimi noktasında yeterli performans göstermediğini düşünmektedirler. Katılımcllar 10 kez Türk eğitim sisteminin beklenen seviyede değer eğitimi yapamadığ1$\mathrm{n} ı$ belirtmişlerdir. Bu husus katılımcıların bir sorun alanı olarak ifade ettiği, Türk eğitim sisteminin bütüncül bir eğitim vermedeki zafiyeti ile de ilişkilendirilebilir. Bir kısım öğretmen adayı Türk eğitim sisteminin milli ve manevi değerleri kazandıramadığını ifade etmektedir. Eğitim sistemini yönlendirenler bu zafiyeti görüp öğretim programlarına ve süreçlerine değerler 
eğitimini entegre etme çabalarına girişmişlerdir. Ancak katılımcılar bu çabaların ve çıktıların tatmin edici olmadığını düşünmektedir.

- K24: Sadece para kazandırmaya odakl, maddiyata önem veren ve insani duygulardan yoksun, puan ve not esasli eğitim yüzünden toplumda rüşvet, adam kayırma, haksızlık ve adaletsizlik artıyor. Bu nedenle değer esaslı bir eğitim şart.

- K41: Ahlaki değerlerin de düzgün aktarılması önemli bence çünkü iyi bir eğitimi pekiştiren unsurlardan birisidir. Günümüzde iyi eğitim almış birçok insanın ahlaki değerlerden uzak kaldığını ve yalnızca kendisini düşündügünü görmekteyiz. Hâlbuki iyi eğitim almış bir insanın çevresine ve ülkesine de faydalı olması gerekir.

Bazı katılımcılar da eğitim sisteminin bilgi aktarımının yanı sıra bu bilginin nasıl faydalı biçimde kullanılacağının da öğrencilere öğretilmesi gerektiğini düşünmektedir. Ayrıca kademelere göre uyarlanmış ve sadeleştirilmiş bir etik eğitiminin başlatılması gerektiğini ifade eden katılımcılar da vardır.

- K13: Eğitim sistemi bireye bilgiyi veriyor ama bunu nasıl doğru kullanacağını öğretmiyor. Yani sonuçta bir bilgi zararlı yönde de kullanabilir ki bunun örneğini atom bombası gibi örneklerde gördük. Bu nedenle etik denen şeyin de okullarda öğretilmesi gerek.

\section{Milli Ĕ̆itime Dair Alınan Kararlarn Eğitim Dışından Kişilerin Alması}

Katılımclardan bir kısmı eğitimle alakalı kararların eğitime ilişkin yeteri kadar birikimi olmayan kişiler tarafından alınmasının, sistemin temel sorunlarından biri olduğunu dile getirmişlerdir. Özellikle zaman zaman eğitimin siyasi tartışmaların bir aracı haline gelmesi öğretmen adayları tarafından eleştirilmektedir. Bunun yerine eğitimin bir devlet politikası haline getirilmesi ve farklı siyasi görüşlerin eğitim söz konusu olduğunda bu politikaları destekleyici ortak bir tutum takınması gerekmektedir.

- K37: Evet, şuna inanırım hep bir şeyin bir üst iyisi olduğuna; kulland1ğımız sistem en iyisi olmayabilir ve eğitim sistemi de bir üst seviyeye çkartılmalı. Ama bu ancak sistemi değiştirme kararı alınan toplantı masalarının çevresinde gerçek eğitimcilerin yani öğretmenlerin olmasında geçer.

- K43: Bence en büyük sorunlardan biri de müfredatlar hayatında bir kez bile ders vermemiş politikacılar tarafından hazırlanıyor. Eğitimin ne ol- 
duğunu bilen birinin hazırladığı sistemin de müfredatın da olumlu sonuçları olacağını düşünüyorum.

Yine bu tema içerisinde öğretmen özerkliğinin düşük olması ve öğretmenlerin eğitsel kararlarda fikirlerini programlara ve öğretim süreçlerine yansıtamamaları bir problem alanı olarak ortaya konmuştur.

- K4: Öğretmenler eğitim sisteminde söz hakkına sahip değiller. Zaten sistem bu yüzden dikiş tutmuyor. Veli ve öğrenci öğretmenden daha fazla etkili. Öğretmenlerin fikirleri sorulmadıkça sistem iyileşmeyecektir.

\section{Eğitimin Paydaşlarnna Yönelik Problemler}

Öğretmen adayları bu tema altında öncelikli olarak ebeveynlerin çocuk yetiştirme hususlarında yaptığı hataların eğitime yansımalarını problem oluşturduğunu ifade etmişlerdir. Bununla birlikte katılımcılar ebeveynlerin bir kısmının çocuklarını yönlendirme ve eğitsel süreçte onlara destek olma konusunda da eksik olduklarını düşünmektedirler.

- K8: Günümüz eğitim sistemini en önemli eksikliklerinden biri aile eğitimidir. Eğitim ailede başlar e çocuk anne babanın aynısıdır. Şimdiki ailelerin çocukları ile sağlıklı bağ kuran, onlara vakit ayıran bir düzenleri yok. Genellikle onları susturmak amacıyla tablet ve telefon verip geçiştiriyorlar. Sonra da çocuğun gelişimi birçok yönden olumsuz etkileniyor.

Bu tema altında ayrıca eğitsel kararların paydaşların tam bir katılımı olmadan alınması ve paydaşların eğitsel karar ve süreçlere etki etmek için yeterli inisiyatif almaması da problemler olarak dile getirilmiştir.

- K38: Eleştirmeye hakkımız var ama her eğitimci, öğrenci, veli yani eğitimin içindeki herkes sürekli bir eleştiri, yerme çabasında. Devamlı eleştiri yapıyorlar ama uygulama yok. Böylece bir nebze kendilerini rahatlatmış oluyorlar. Sonra aynı düzen devam ediyor. Eleştirmeye verdiğimiz çabayı değiştirmeye de verseydik iyi bir yerlerde olabilirdik.

$\mathrm{Bu}$ tema kapsamına son olarak paydaşlar arasında yeterli bir iletişim olmaması da problem alanı olarak belirtilmiştir.

- K12: Öğrenci, öğretmen ve veli bir bütün oluşturan parçalardır. Bu parçalar arasında yeterli iletişimi sağlamak gerekiyor yoksa uyum sağlanamazsa bir çatışma doğacaktır ve bugün yaşadığımız da bu. 


\section{Lisans Ĕ̆itiminin Niteliği}

Öğretmen adaylarına göre lisans eğitiminin niteliği ve kendisinden beklenen işlevi yerine getirememesi, eğitimin sorunlarından biri olarak öne çımaktadır. Katılımcıların lisans eğitimi kademesinde olmaları ve bizzat ilgili sisteminin bir paydaşı olmaları, bu kademeye dair sorunları ilk elden gözlemlemelerine imkân sağlamıştır. Lisans eğitiminin ilgili olduğu alana ilişkin yeterli bilgi ve beceri kazandırmadığı katılımcıların üzerinde durduğu hususlardan biridir. Bu noktada lisans eğitimine erişimin halen düşük seviyede olması ve lisans eğitiminin kendinden önceki kademelerin başlatıış olduğu teorik eğitim silsilesini devam ettirerek yalnızca bilgi odaklı bir anlayışa sahip olması sorun alanları olarak ifade edilmiştir. Bir kısım katılımcı bu durumu öğretmen yetiştirme sistemi ile ilişkilendirmiş ve de özellikle çeşitli alanlardan beceri gerektiren meslek veya disiplinlerin yalnızca teorik temelli aktarımını, lisans eğitiminin işlevini yerine getirememesi olarak yorumlamıştır.

- K37: Evet, tam 12 yıl eğitim alıp ilköğretim ve ortaöğretim hayatını bitiriyoruz. Aldığımız dersler hep ortaktı ve teorikti...........Tam diyoruz ki evet 12 teorik yılı bitirdik ve artık yapacağımız mesleğin ilk adımlarını üniversitelerimizde atacağız ancak yine önümüze teorik dersler yı̆̆1lıyor..........Her şeyi mesleğe başladıktan sonra öğreneceksek bu kadar uzun yıl eğitim almamız niye. Ben üniversiteleri teorik dersler yüzünden mesleğe geç kalınmışlık olarak görüyorum.

Katılımclardan bazıları ise lisans eğitiminin araştırma, sorgulama, problem çözme, disiplinler arası çalışma, inovasyon gibi becerilere odaklanmadığını ve bu yetilerin lisans eğitimi aracılığı ile geliştirilemediğini ifade etmiştir.

- K6: Üniversiteler sadece iş imkânı sağlamak veya teorik eğitim almak için gidilen yerler olmamalı. Üniversitelerde sosyal ilişkiler, birtakım çağdaş beceriler ve aslında hayat öğrenilmeli.

\section{İthal Eğitim Sistemlerinin Uygulamalarnnn Transfer Edilmesi}

Öğretmen adaylarının bir kısmı farklı ülkelerin eğitim sistemlerine ilişkin uygulamaların Türkiye gerçeklerine uyarlanmadan aynen transfer edilmesini bir problem olarak görmektedirler. Sosyal yapısı, demografik özellikleri, eğitim felsefesi farklı ülkelerin eğitim sistemlerinin yeteri kadar inceleme- 
den ve ne sonuçlar vereceği planlanmadan kullanılması eğitimde birçok başka problemin oluşmasına zemin hazırlamaktadır. Eğitimin evrensel ve tüm toplumlar tarafından tatbik edilebilecek gerçekleri olduğu gibi yerel ve yalnızca o ülkeye dair özellikler tarafından belirlenen bir yönü de mevcuttur. Bu ilke göz önüne alınmadan başka bir ülkenin eğitim sisteminin bütüncül bir bakışla kopyalanması, katılımcılar açısından eğitim sisteminin sorunlu yönlerinden biridir.

- K4: Diğer bir sorun ise kendi eğitim sistemimiz yok sürekli başka yerlerden alıyoruz. Sonuçta herkesin örf, adet ve gelenekleri farklı bu yüzden öğrenci bu sistemi benimseyip uygulayamıor.

- K23: Özellikle ülkemizde sürekli olarak başka ülkelerin sistemleri kullanılmaya çalışılmakta fakat gerek kültürel farklılıklardan gerekse ulusal amaç ve hedef farklılıklarından kaynaklı olarak başarıya ulaşılamamaktadır.

\section{Yetişkin Eğitimine Yeteri Kadar Önem Verilmemesi}

Öğretmen adayları günümüzde hayat boyu öğrenme kavramının ortaya çıkmasıyla önemi tekrar fark edilen yetişkin eğitimi olgusunun Türk eğitim sistemi açısından yeteri kadar önemsenmediğini düşünmektedirler. Halk eğitiminin gerçekleştirilmesine dönük imkân ve uygulamaların artırılarak çeşitlendirilmesi, toplumun eğitim seviyesini yükseğe taşıyacağından ciddi biçimde ele alınmalıdır. Aksi takdirde bir toplumu oluşturan bireylerin aldıkları eğitim yalnızca örgün eğitim kurumlarında geçirdikleri süreçlerle sınırlı kalacaktır. Bu çalışma kapsamında ifade edilen birtakım etmenlerin örgün eğitiminin nitelik ve etkisini düşürdüğü göz önüne alındığında bireyler gerçek yaşamın problemlerini çözme, fırsatları değerlendirme, girişimci olma ve hayatı boyunca ihtiyaç duyduğu bilgi ve yeti gelişimini sağlama konusunda eksik bir beceri setine sahip olacaklardır.

- K26: Eğitim sadece öğrenciler için değil bence. Yetişkin halk için de kütüphaneler ve etkinliklerle halk da eğitilmeli.

\section{Diğer Sorunlar}

Daha az sayıda öğretmen adayının sorun olarak ifade ettiği konular bu başlık altında ele alınmıştır. Araştırmada öğretmen adayları beş kez eğitimde teknolojinin yanlış yönde ya da yetersiz kullanımını bir problem olarak 
değerlendirmişlerdir. Burada özellikle eğitim teknolojilerine yüklenen yanlış anlam, yani teknolojinin öğretim süreçlerinde asli bir unsur kabul edilmesinin problem oluşturduğu ifade edilmiştir. Katılımcılar beş kez okul öncesi eğitime erişimin sınırlı olması ve eşitsizlik içermesi durumunu, beş kez okullaşma oranının düşük olmasını ve iki kez eğitimin bilimin doğurgularına göre düzenlenmemesini problem olarak belirtmişlerdir. Bununla birlikte birer kez ise eğitimin esnekliğe imkân vermeyen merkeziyetçi yapısı, mesleki eğitime yeterli önem verilmemesi ve toplumsal cinsiyet eşitsizliği problem olarak dile getirilmiştir.

- K13: Okullardaki akıllı tahtaları yaşı ilerlemiş veya kendini gelişime kapamış öğretmenlerin kullanmasının zor olduğunu düşünüyorum. $\mathrm{O}$ zaman aktif kullanılamayan materyaller eğitime fayda sağlayamaz.

- K21: Eğitim sistemindeki en büyük problemlerden biri teknolojiyi geliştiremememiz ve elimizdeki teknolojiyi bile düzgünce kullanamamamız..... Eğitim sisteminde bir ara Fatih projesi uygulandı ama başlarda mantıklı olduğu düşünülen bu proje sonraları bir sürü sıkıntı çıtı. Sonra öğrencilere PC tabletler dağıtıldı, onların da bir işlevi olmadı. Umarim bunlara çözüm bulunur.

- K51: Bu teknolojik unsurların eğitimde mutlak başarıyı getireceğini düşünüyoruz. Hiçbir teknolojik alet öğretmenin yerini tutamaz; bizim öğretmene yatırım yapmamız lazım.

- K8: Eğitimdeki temel problemlerden biri de okullaşma oranındaki yetersizliktir. PISA ile ilgili dersler de konuşulurken istatistiklerimizin OECD ortalamasının altında olduğunu görmüştük.

- K43: Eğitim sistemimizin bir amacı olmalı. Bana göre, eğitim sistemimiz bilim ekseninden uzaklaşmış olması eğitim sisteminin amacına engel oluyor. Neden hep elde tutulur projeler, gelişmiş sistemli aletler ve teknoloji konusunda gelişmiş ülkelerden geride kalıyoruz. Bunun çok sebebi var ama biri de bilimsel düşünmememiz ve bilimsel düşünme yöntemlerini bilen, uygulayan bireyleri yetiştirmiyor olmamı.

- K44: Okul öncesi eğitim tamamen parasız olursa herkes erişebilir. Ama okul öncesi eğitim yayginlaşmadığı için bazı öğrencilerin okula uyumu çok zor oluyor ve bu öğrenciler yeterli eğitim alamıyor. 


\section{Tartışma ve Sonuç}

Araştırmada öğretmen adaylarının Türk eğitim sisteminin problemlerine ilişkin düşüncelerini belirlemek ve bu düşüncelerin dünyadaki eğitime dair küresel ve güncel problemler ile örtüşüp örtüşmediğini analiz etmek amaçlanmıştır. Öğretmen adaylarının görüşleri, eğitimin işlevlerini yerine getirememesi, ezberci yapı, fırsat ve imkân eşitsizliği, lisans eğitiminin nitelik ve işlevi, değer eğitimi, eğitimin öz farkındalık kazandıramaması, eğitim sisteminin istikrarsız oluşu, öğretmene ilişkin süreçler ve politikalar, kaynak eksikliği, ithal eğitim sistemlerinin uygulamalarının transfer edilmesi, yetişkin eğitimi, eğitimin paydaşlarına yönelik problemler gibi başlıklarda yoğunluk göstermektedir. Bu sorunların birçoğu daha önce ele alınan çeşitli eğitim raporları ve analizleri ile akademik çalışmalarla birebir örtüşmektedir.

Alanyazın incelendiğinde Türk eğitim sisteminin sorunlarına yönelik öğretmen adaylarının görüşlerine başvuran çalışmaların sayıca az olduğu görülmektedir. Yılmaz ve Altınkurt (2011) tarafından gerçekleştirilen çalışmada öğretmen adayları Türk eğitim sisteminin sorunlarına ilişkin problem kaynağı olduğunu düşündükleri unsurları belirtmiştir. Bu bağlamda merkezi sınavlar, ezberci eğitim, öğretmenlerin niteliği, öğretmen atama ve yetiştirme sistemi, eğitime erişimde eşitsizlikler gibi alanların problemli olduğuna ilişkin bulgu çalışmamızla paralellik göstermektedir. Yine mesleki ve teknik eğitim, rehberlik faaliyetleri, eğitimin merkeziyetçi yapısı, taşımalı eğitim ve okul öncesi eğitim başlıkları her iki çalışmada da problemli unsurlar olarak belirlenmiştir.

Bu iki çalışmanın arasında geçen süre göz önüne alındığında öğretmen adaylarının eğitim sisteminin problemlerine dönük algıları büyük benzerlikler taşımaktadır. Günümüzde bilimsel, sosyolojik, ekonomik, toplumsal ve psikolojik alanlarda yaşanan yoğun değişim dalgasının varlığına rağmen görüşlerin bu kadar paralel olması yani görüşlerin değişimlerden etkilenmemiş olması, öğretmen adaylarının bu değişimleri yeteri kadar takip etmediği şeklinde yorumlanabilir. Sezer (2020) çalışmasında öğretmen adaylarının, Türk milli eğitiminin genel amaçlarının gerçekleşme düzeyine ilişkin görüşlerini incelemiştir. Çalışmanın sonuçlarına göre öğretmen adayları milli eğitimin amaçlarının yüksek düzeyde gerçekleşmediğini savunmuştur. Öğretmen adayları milli eğitimi en çok vatandaş yetiştirme ve öğrenciye 
milli değerleri benimsetme alt amacında başarılı bulduklarını ifade etmiştir. Bu bulgu değerler eğitiminin problemli olduğunun belirlendiği çalışmamızla çelişiyor görünse de öğrencilerin çağdaş eğitim felsefesine göre kişisel gelişimlerinin sağlanmasının öncelenmesi gerektiğine dair bulguyu desteklemektedir. Bu noktada bireylerin toplumsal normlara göre birbirleriyle benzer bir şekilde yetiştirilmesi uzun yıllardan bu yana eğitim sistemlerinin önemli amaçlarından biri olagelmiştir. Ancak özellikle son yıllarda eğitime dair anlayışta vuku bulan değişiklik bireysel farklılıklara duyarlı ve bireyin kendi kişisel gelişimini sağlayacağı öğretimsel tercihleri yapabilmesine imkân veren düzenlemeleri gündeme taşımıştır. Bu nedenle Sezer (2020)'in çalışmasında eğitimin toplumsal amaçlarının yeterli düzeyde gerçekleştirildiği düşüncesine, bireysel gelişimin yeterli olarak sağlanmadığı düşüncesinin eşlik etmesi bu çalışmanın bulgularını desteklemektedir. Zira ilgili çalişmada Türk milli eğitiminin, sorumluluk sahibi ve dengeli karaktere sahip birey yetiştirmede orta düzey bir performans gösterdiği bulgulanmıştrr. Yine milli eğitim sistemi bireyleri hür ve bilimsel düşünme gücü ile geniş bir dünya görüşüne sahip kılmada düşük, ilgi ve yeteneğe göre yetiştirme ile mesleğe hazırlamada ise oldukça düşük bir performans göstermektedir.

Geçmiş yıllarda belirtilen bazı sorunların "Özel dershaneler sorunu" (Yılmaz \& Altınkurt, 2011, s. 957) bu çalışmada yer almadığı görülmektedir. Bu doğrultuda Milli Eğitim açısından bakıldığında mevcut dile getirilen sorunlardan bazılarının çözüm bulduğu görülmektedir. Ama öğretmen adaylarının dünyadaki gelişimleri yakından takip etmedikleri ve küresel bazlı eğitime dair sorunlara yabancı kaldıkları da aşikârdır. Bu açıdan çeşitli akademik çalışmalarda yapıcı öneriler sürekli sunulmaktadır. Özellikle öğretmen standartları konusunda MEB-YÖK arasındaki uyum önemsenmektedir. Öğretmen ve diğer personel denetim standartları oluşturulmalıdır. Öğretmen yetiştirme standartlarının oluşturulması ve bunların lisans programları ile uyumunun sağlanması gerekir (Yayla, 2015, s. 118).

Alpaydın (2018) tarafından hazırlanan raporda da Türkiye'nin eğitim sisteminin güçlendirilmesi gereken alanları incelenmiştir. Buna göre insan odaklı bir eğitim anlayışının yeterli biçimde uygulanamadığı dikkat çekilen raporda, eğitimin halen ideolojik ve özellikle de ekonomik odaklı bir anlayışla yürütüldüğü belirtilmektedir. Bununla birlikte toplumun tarihsel ve düşünsel mirasının yansıtıldığı eğitim programları, temel kalite standartlarını karşılayan okullar ve bunların yönetiminin devredileceği liyakat sahibi 
liderlerin eksikliği de eğitimin performansını etkilemektedir. Öğrenme sürecini devam ettiren eğitimci kadrosu, yerinden okul merkezli bir yönetim anlayışı ve bu anlayışın getireceği esneklikler, adil bir performans değerlendirme ve teşvik sistemi ile güçlü kurumsal iletişime sahip eğitim kurumları da eğitim sisteminin sorunlu noktaları olarak değerlendirilmektedir.

Hem Millî Eğitim Bakanlığı'nun hem de Yükseköğretim Kurumu'nun bugün itibari ile büyük çabalar göstererek problemlere çözüm aradığı mevzulardan birisi de mülteciler ve eğitim konusudur. Geçici koruma kapsamındaki Suriyeli vatandaşların sayısı Eylül 2019 itibariyle 3.658.250'dir (Göç İdaresi Genel Müdürlüğü, 2019). Sadece Suriye değil Irak'ta yaşayan Arap ve Türkmenlerin de Türkiye'ye göç ettikleri ve Türkiye'nin bu kişilere geçici koruma imkânı sağladığı görülmektedir. Tüm bu göç dalgaları sadece sosyal problemleri beraberinde getirmemiş aynı zamanda eğitim problemlerini de doğurmuştur. Göç eden öğrenciler Türk öğrencilerin okudukları sınıflara dağıtılmış ve farklı etnik yapılara sahip öğrencilerin Türk öğrenciler ile kaynaşarak adaptasyon problemi aşılmaya çalışılmak istenmiştir. Türk öğrenciler başta olmak üzere velileri de bu duruma tepki göstermeye başlamışlardır. Ama buradaki en büyük problemi yaşayan öğretmenlerdir. Öğretmenler farklı düzeydeki yabancı uyruklu bu öğrencileri sınıfa adapte etmekte ve eşit düzeyde sınıf ortamı oluşturmakta sorunlar yaşamakla beraber dil farklılıklarından doğan eksikliği tamamlamak için üstün çaba göstermişlerdir. Güler (2012, s.133)'e göre dil öğretimi yapan öğretmenlerin dilin inceliklerine hâkim olması, bunları yerinde, zamanında izah edebilmesi ve ayırt edici örneklerle öğrenciye seslenebilmesi özellikle kelime öğretiminde son derece mühim yer tutar. Aksi hâlde dil-kültür ilinkisiyle renklenen dil öğrenme/öğretme faaliyetinin öğrenene/öğretene verdiği zevk azalacak ve hedef dile olan talep yeterince karşılanamayacaktır. Bu özelliklerin tüm öğretmenlerde olması gerekliliği yadsınamaz bir olgu olarak güncel gelişmeler ışığında karşımıza çıkmaktadır.

Bu bağlamda Erdem (2017) yaptığ çalışmada mülteci öğrencilerin bulunduğu sınıflarda görev yapan sınıf öğretmenlerinin yaşadıkları sorunlar konu edilmiştir. Çalışmanın sonuçlarına göre öğretmenler süreçte, öğretim içeriğini öğrenciye görelik ilkesine göre revize etme, öğrenci özelliklerine uygun öğretim stratejileri kullanma, uygun öğretim araç ve gereçleri seçme ve bunları etkili kullanma, ölçme araçları geliştirme ve değerlendirme unsurlarına dönük ihtiyaç hissettiklerini ifade etmişlerdir. 
$\mathrm{Bu}$ çalş̧mada ise öğretmen adaylarının eğitime dair görüşlerinde bu tür farklı ve karışık sınıf ortamlarına dair sorunlar bulunmamaktadır. Öğretmen adaylarının bu sorunu görmezden gelmeleri ve Türkiye'nin bu sorunu yakından yaşamasına rağmen öğretmen adaylarının bu soruna karşı bir fikirlerinin olmaması düşündürücüdür. Bunu doğuran etmenlerden biri de yükseköğretim kurumlarındaki derslerde bu duruma yönelik yeterli bilgilendirme ve formasyon eğitiminin verilememesi durumudur.

Çin'in Wuhan kentinde 2020 yılında ortaya çıkan ve tüm dünyayı etkisi altına alan Covid-19 virüs salgını ülkemizde de etkisini göstermektedir. Türkiye olarak virüsün hissedilmeye başlandığı ilk günden itibaren çalışmalara başlanarak etkinin en aza indirilmesi hedeflenmiştir. Bu doğrultuda tüm eğitim kurumlarında yüz yüze eğitimlere ara verilmiş ve senkron ya da asenkron yöntemlerle uzaktan eğitime başlanmıştır. Bu doğrultuda öğretim elemanları/öğretmenler ve öğrenciler farkı teknolojik yollara başvurarak çok da hazırlıklı olmadıkları bir eğitim ortamında kendilerini bulmuşlardır. Bu durum eğitim camiasını bir müddet yormuş ve uzaktan eğitimin önemini ortaya çıkarmıştır. Öğretmen adaylarının uzaktan öğretim sistemleri ile ilgili eğitimsel problemleri dile getirmemesi bu alana ve bu problemlere ne kadar da uzak olduğunun işaretidir.

Bu çalışmada görülen sonuçların başında öğretmen adaylarının kamuoyunda tartışılan eğitim problemlerine duyarlı oldukları ama dünya genelinde gerçekleşen ya da gerçekleşmesi muhtemel eğitim problemlerine hazırlıksız oldukları görülmektedir. Bu doğrultuda öğretmen adaylarına gerek formasyon dersleri gerekse akademik araştırma sahalarında küresel eğitim sorunları ve öngörülecek problemler doğrultusunda eğitimler verilmesi önem arz etmektedir. Ayrıca sosyo kültürel sorunların çözümü için öğretmen adaylarının atanabilecekleri yerlere ilişkin farkındalıklarını arttırmaya yönelik bilgilendirmeler yapılabilir (Sever, Aktaş, Şahin ve Tunca, 2015, s. 15). Eğitim alanında, eğitimi etkili ve önemli kılan en önemli etmen olan öğretmenin doğabilecek problemler karşısında hazırlıklı ve bu alanlarda donanımlı olmasıdır. Eğitimin ana saç ayakları olan öğretmen, öğrenci ve veli üçgeninde, öğretmenin bu problemler karşısında hazır ve yetkin olması diğer ayakları (veli ve öğrencileri) rahatlatacak ve eğitim kalitesini arttıracaktır. Küresel problemlerin bilinmesi, bu doğrultuda ön çalışmaların yapılması ve teknolojik gelişmelerin takibi hem ülkemiz açısından hem de 
ülkemizdeki eğitim ortamlarını takip ve tercih eden uluslararası öğrenciler tarafından önemli konular olarak ele alınabilir.

Kültürel bazda sağlık kültürü, teknoloji kültürü, ekonomi kültürü vb. birçok alan, eğitim ile iç içe durumlar arz edebilir. Bu doğrultuda öğretmen adaylarının farkındalığını artırmak ve bu kültür havzaları ile ilgili bilgilendirmeler yapmak, kaynak araştırmalarına yöneltmek, ar-ge çalışmalarına dâhil etmek, bu çalışmalara maddi ve manevi destekler sunmak öğretmen adaylarını güçlü kılacak ve mesleğin başta itibarı olmak üzere tüm etki alanlarında pozitif sonuçlar verecektir. 


\title{
EXTENDED ABSTRACT
}

\section{Pre-Service Teachers' Approaches to the Problems of the Turkish Education System and Levels of Closeness to Global Problems on a Cultural Basis}

\author{
Eray Eğmir -Halit Çelik \\ Afyon Kocatepe University, Kütahya Dumlupınar University
}

Turkey which is an important country of Europe in terms of student potential allocates a critical part of its budget every year for performing and developing the educational activities. However, since the Turkish education system has different problems in every period, struggling with these problems and producing temporary or permanent solutions within the framework of these problems have been issues that concern all stakeholders of education, especially the National Education community. Education is directly affected by other social, political and economic problems as well as the problems in its context. In this regard, stakeholders of the education system also have to take measures to reduce the negative effects of problems in other areas.

In their study, Yllmaz and Altınkurt (2011, p. 944-945) compiled many problems related to the education expressed by various institutions and organizations in a table and stated that the efforts made for the solution of these problems were insufficient. Problems in the field of education are handled as the subject of the studies created at the local level in addition to the studies carried out for the country. The overlapping of the problems on a local basis with the problems across the country shows that education problems exist systematically. But whether these problems are the main problems of the Turkish education system and the place of these problems in the development and change in the field of education on a global basis are the situations that need to be discussed.

Considering the report, evaluation, academic study and collected data regarding the education and educational problems summarized above, it is determined that the general valid problems are superficial and unrelated problems. In the developing and changing world education structure, it can be said that there are difficulties in following the world literature regarding 
new and changing problem titles related to education field and new understanding and ideas are not formed in this direction. So, this study aims to determine whether the pre-service teachers' opinions about the problems of the Turkish Education System overlap with global and new problems/culture areas in the world.

The research is a research designed in a qualitative design, and it is aimed to analyze the opinions of the pre-service teachers about the problems of the Turkish education system with a phenomenological approach. The study group of the research consists of students studying at the education faculty of a state university in the Aegean Region in the 2019-2020 academic year determined by the maximum diversification method. Pre-service teachers were selected from five different departments and four different grade levels of the education faculty where the study group was selected, and in this way, it was aimed to collect data with a wide participation. The data needed in the study were collected by using a semi-structured interview form prepared by researchers taking into account the opinions of an educational sciences and a language specialist. In the interview form prepared by the researchers, the participants were asked to express the problems they consider important in the Turkish education system due to their reasons.

In order to ensure the credibility and consistency of the study, the data presented were directly supported by quotations. However, during the coding of the data, the data were individually encoded by the two researchers and in order to check the consistency between the coders, the consensus between the coders, called the internal coherence in the Miles and Huberman model, was calculated. The rate was found as $\% 90$.

Pre-service teachers' views showed that, the inability of education to fulfill its functions, having a structure that gives importance to memorization, equality in opportunity, quality of undergraduate education, value education, instability of the system, policies regarding the teacher, lack of resources, transfer of implementations of imported education systems, adult education, problems for education stakeholders areas are the problem areas of Turkish education system. Besides, wrong or inadequate use of technology in instructional activities, limited and unequal access to preschool education, low enrollment rate, the situation that education is not arranged according to the implications of science, the centralized structure of education 
that does not allow flexibility, insufficient attention to vocational education and gender inequality are mentioned as problems.

When the literature is examined, it is seen that the studies referring to the opinions of prospective teachers regarding the problems of the Turkish education system are few in number. In the study conducted by Yllmaz and Altnkurt (2011), preservice teachers stated the factors that they thought were the source of problems related to the problems of the Turkish education system. In this context, the finding related to the problematic areas such as central exams, having a structure that gives importance to memorization, the quality of teachers, teacher appointment and training system, and inequality in access to education is in line with our study. Again, vocational and technical education, guidance activities, centralization of education, mobile education and pre-school education titles were identified as problematic elements in both studies.

Considering the time elapsed between these two studies, the perceptions of teacher candidates towards the problems of the education system have great similarities. Despite the presence of an intense wave of change in the scientific, sociological, economic, social and psychological fields today, it can be interpreted that the teacher candidates do not follow these changes sufficiently because of the opinions are so parallel, that the opinions are not affected by these changes. According the results of this, it is seen that teacher candidates are sensitive to the education problems discussed in the public, but they are not prepared for the education problems that occur or are likely to happen around the world. In this direction, it is important to provide education and academic research activities to teacher candidates in line with global education problems. The most important factor that makes education effective and important in the field of education is that the teacher is prepared and equipped in the face of problems that may arise. In the triangle of teacher, student and parent, who are the main pillars of education, the fact that the teacher is ready and competent against these problems will relieve the other feet (parents and students) and increase the quality of education. Knowing global problems, conducting preliminary studies in this direction and following technological developments can be considered as important topics both by our country and by international students who prefer and follow educational environments in our country. 


\section{Kaynakça / References}

Akbaşlı, S., Okan, D. İ. Ş., ve Durnalı, M. (2020). İlkokul öğretmenlerinin karşılaştıkları yıldırma davranışları ile motivasyon düzeyleri arasındaki ilişki. Pamukkale Üniversitesi Eğitim Fakültesi Dergisi, 49, 564-581.

Alpaydın, Y. (2018). Geleceğin Türkiye'sinde eğitim. İLKE Yayınları: 12, İstanbul: Limit Ofset

Ay, D. (2014). Eğitim sektörü raporu. TSKB (Türkiye Sınai Kalkınma Bankası) Ekonomik Araştırmalar.

Baltacı, A. (2017). Nitel veri analizinde Miles-Huberman modeli. Ahi Evran Üniversitesi Sosyal Bilimler Enstitüsü Dergisi, 3(1), 1-15.

Büyüköztürk, Ş., Kılıç Çakmak, E., Akgün, Ö. E., Karadeniz, Ş., ve Demirel, F. (2013). Bilimsel araştırma yöntemleri. (15. baskı). Ankara: Pegem Akademi Yayınc1lik.

Demir, M. K., ve Arı, E. (2013). Öğretmen sorunları-Çanakkale ili örneği. Ondokuz Mayıs Üniversitesi Ĕ̆itim Fakültesi Dergisi, 32(1), 107-126.

Eğitim Reformu Girişimi (ERG) (2019). Öğretmen politikalarnnda mevcut durum ve zorluklar. İstanbul: ERG Sabanc1 Üniversitesi, https://www.egitimreformugirisimi.org/yayin/egitim-izleme-raporu-2019ogretmenler/adresinden 27.04. 2020 tarihinde erişilmiştir.

Eğitim-Sen (2019). 2018-2019 eğitim-öğretim yılında eğitimin durumu. http://egitimsen.org.tr/2018-2019-egitim-ogretim-yilinda-egitimin-durumuraporu/adresinden 24.03. 2020 tarihinde erişilmiştir.

Erdem, C. (2017). Sınıfinda mülteci öğrenci bulunan sınıf öğretmenlerinin yaşadıkları öğretimsel sorunlar ve çözüme dair önerileri. Medeniyet Ĕgitim Araştırmalarn Dergisi, 1(1), 26-42.

Filiz, B., ve Durnali, M. (2019). The views of pre-service teachers at an internship high school on pedagogical formation program in Turkey. European Journal of Educational Research, 8(2), 395-407.

Göç İdaresi Genel Müdürlüğü (2019). Geçici koruma. https://www.goc.gov.tr/gecicikoruma5638 adresinden 27.04. 2020 tarihinde erişilmiştir.

Güler, E. B. (2012). Yabancılara türkçe öğretiminde "öğretmen” unsuru. International Journal of Social Science, 5(2), 129-134.

Karip, E. (2019). Eğitim değerlendirme raporu. Ankara: TED Yayınları.

Limon, İ., ve Durnall, M. (2018). Doktora öğrencilerinin doktora eğitimi ve öğretim üyelerine yönelik metaforik algları. Sakarya University Journal of Education, 8(1), 26-40. 
MEB. (2019a). Millî eğitim istatistikleri, örgün eğitim 2018/19. https://sgb.meb.gov.tr/meb_iys_dosyalar/2019 09/30102730_meb_istatistikl eri orgun egitim 2018 2019.pdf adresinden 24.03. 2020 tarihinde erişilmiştir.

MEB. (2019b). Millî Ĕ̆itim Bakanlı̆̆ı 2019-2023 stratejik planı. http://sgb.meb.gov.tr/www/mill-egitim-bakanligi-2019-2023-stratejik-planiyayinlanmistir/icerik/368 adresinden 27.04.2020 tarihinde erişilmiştir.

MEB. (2018). 2023 eğitim vizyonu. Ankara: Milli Eğitim Bakanlı̆̆ı. http://2023vizyonu.meb.gov.tr/doc/2023 EGITIM VIZYONU.pdf adresinden 27.04.2020 tarihinde erişilmiştir.

Orhan, A., ve Acar, F. E. (2018). Göz ardı edilen program ve Türkiye'deki yansımaları. Eğitimde Kuram ve Uygulama, 14(3), 292-305. doi:10.17244/eku.375778

Özyılmaz, Ö. (2020). Türk milli eŏitim sisteminin sorunları ve çözüm arayışları (7. baskı). Ankara: Pegem Akademi Yayınları.

Posner, G. J. (1995). Analyzing the curriculum. New York, NY: McGraw-Hill, Inc

Sever, D., Aktaş, B., Şahin, S., ve Tunca, N. (2015). Pedagojik formasyon sertifika programı öğrencilerinin öğretmenlik mesleğine başladıklarında karşılaşabileceklerini düşündükleri sorunlar. Anadolu Üniversitesi Eğitim Bilimleri Enstitüsü Dergisi, 5(2), 1-23.

Sezer, Ş. (2020). Öğretmen adaylarının görüşlerine göre Türk milli eğitiminin genel amaçlarının gerçekleşme düzeyi. OPUS Uluslararası Toplum Araştırmaları Dergisi, 15(24), 2269-2296.

Ünal, A., Yavuz, M., ve Küçüker, E. (2011). İlköğretim müfettişlerinin öğretim yılı sonu raporlarına göre Konya ili eğitim sorunlarının değerlendirilmesi. $\mathrm{Ku}$ ram ve Uygulamada Ĕ̈itim Yönetimi, 17(2), 247-276.

Yayla, A. (2015). Nitelikli öğretmenlerin yetiştirilme sürecinde yeni arayışlar: Sorunlar ve çözüm önerileri. TYB Akademi Dil Edebiyat ve Sosyal Bilimler Dergisi, $13,109-122$.

Yıldırım, A. (2013). Türkiye'de öğretmen eğitimi araştırmaları: Yönelimler, sorunlar ve öncelikli alanlar. Eğitim ve Bilim, 38(169), 175-191.

Yıldırım, A. ve Şimşek, H. (2011). Sosyal bilimlerde nitel araştırma yöntemleri. Ankara: Seçkin Yayıncılik.

Yılmaz, K., ve Altınkurt, Y. (2011). Öğretmen adaylarının Türk eğitim sisteminin sorunlarına ilişkin görüşleri. Uluslararası Insan Bilimleri Dergisi, 8(1), 942-973. 


\section{Kaynakça Bilgisi / Citation Information}

Eğmir, E. ve Çelik, H. (2021). Öğretmen adaylarının Türk Eğitim sisteminin sorunlarına olan yaklaşımı ve kültürel bazda küresel problemlere yakınlık düzeyleri. OPUS-Uluslararası Toplum Araştırmalarn Dergisi, 17(34), 940-979. DOI: 10.26466/opus.773110 